\section{Fractality and Lacunarity of Turkish Cities}

Ceyda İlhan¹, ORCID: 0000-0002-5016-296X

Necmi Gürsakal2, ORCID: 0000-0002-7909-3734

\section{Keywords}

City Morphology; Fractal Geometry; Lacunarity, Complexity

\section{Article Information}

Received:

08.11.2020

Received in Revised Form:

25.01.2021

Accepted:

29.01.2021

Available Online:

30.01.2021

Article Classification:

Research Article

\section{Contact}

1. Faculty of Architecture, Bursa Uludag University, Bursa, Turkey ceydailhn@gmail.com

2. Faculty of Engineering and Architecture, Fenerbahçe University, Istanbul, Turkey negursakal@gmail.com 


\section{Türk Kentlerinin Fraktalite ve Lakunaritesi}

Ceyda İlhan ${ }^{1}$, ORCID: 0000-0002-5016-296X

Necmi Gürsakal2, ORCID: 0000-0002-7909-3734

\section{Anahtar Sözcükler}

Kent morfolojisi; Fraktal Geometri; Lakunarite; Karmaşıklık.

\section{Makale Bilgileri}

Alind1:

08.11.2020

Revizyon Kabul Tarihi:

25.01.2021

Kabul Edildi:

29.01.2021

Erişilebilir:

30.01.2021

Makale Kategorisi:

Araştırma Makalesi

\section{İletişim}

1. Mimarlık Fakültesi, Bursa Uludağ Üniversitesi, Bursa, Turkey ceydailhn@gmail.com

2. Mühendislik ve Mimarlık Fakültesi, Fenerbahçe Üniversitesi, Istanbul, Turkey negursakal@gmail.com 


\section{INTRODUCTION}

Considering that only $30 \%$ of the world's population was urbanized in 1950, urbanization is a relatively new global issue (Bettencourt et al., 2010: 912). But later urbanization has accelerated and continues at great speed. History of urbanization can be followed as an animation from this source (Url-1). According to the data of the United Nations population fund in October 2011, it was recorded that approximately half of the world population of 7 billion live in cities. According to the UN, by 2050, two thirds of the world's population will live in cities (Meredith, 2018). In addition, according to UN_HABITAT data, while cities are responsible for $75 \%$ of energy consumption in the world; $80 \%$ of the gross national product is produced in urban areas (Erdoğan, 2015:2). In almost all countries, people migrate from the countryside to the cities where they find more opportunities.

Urban morphology is constantly changing and transforming reasons such as natural factors, sociocultural structure, economic forces, transportation facilities, migration and demographic change, political decisions and planning regulations, urban transformations, architectural tastes, and the creation of new attractions. Besides the variables of each city and their effect rates being different from each other; different variables may have more dominant effects at different times even for the same city (Illhan and Ediz, 2019; Larkham and Adams, 2019: 74). As a result of all this process, a public image emerges. "Any city has a public image that is the overlap of many individual images," said Kevin Lynch (1960). In a way, fractality and lacunarity can be thought as a way of measuring this image quantitatively.

Cities are like living systems and fractal features such as non-linearities, self-similarity at different scales are fundamental to the very existence of cities (Bettencourt et al., 2010). It has been stated that fractal dimension and lacunarity are complementary. This fact led us to the clustering of Turkish cities by using these two variables together. In this article for the first time, fractal dimensions and lacunarity coefficients of physical urban pattern of the 81 cities in Turkey were calculated.

Inspired by a site where 3D visualization of the population distribution in the world is made with data from the Global Human Settlement Layer using "satellite images, geographical information 
and census data" (Url 2), it has been assumed that the majority of the population of the province live in urban areas. In this direction, Turkey Statistical Institute website 2018 population data were taken as a parameter to investigate the significance level of the effect of the population of the province on the urban pattern (TUIK, 2018). Based on the studies that stated that the city size and morphology are also related to economic factors, the 2018 data on gross domestic product (GDP) per capita by province (as dolar) obtained from the TEPAV website (Düşündere, 2019) as an indicator of the urban economy was included in the study.

In line with the obtained data, the following questions were asked to test a large number of hypotheses for the purpose of the study:

- Are the distributions of fractal dimensions and lacunarity coefficients in this dataset suitable for normal distribution?

- Is there a relationship between fractal dimensions and lacunarity coefficients? If the distribution of fractal dimensions is in the form of a two-moded distribution, what does this mean?

- Are larger cities alike, can we examine whether large or small cities are similar through multivariate cluster analysis?

- What is the meaning of a city's fractal dimension or lacunarity coefficient to be outlier?

- How do these coefficients that we talk about relate to variables such as population or income per capita of each province?

The article is organized in four sections. After the introduction, there is a literature research section in which basic information about fractality and lacunarity and their study areas are introduced. While the analysis process and results of Turkish cities are presented in the third section which is the application section; the discussion and conclusion section includes an overview of the findings and ideas for future research.

\section{FRACTALITY AND LACUNARITY}

Euclidian geometry dates back to 2000 years. "Fractals go back a long way to the 60's through ideas in location theory involving power laws in rank-size and central place theory" (Batty, 1994). Fractal geometry is mostly new and started in the 1975 with the discovery of Benoit Mandelbrot. "This world was fractal. A fractal has been defined as a rough or fragmented geometric shape that can be split into parts, each of which is (at least approximately) a reduced-size copy of the whole, this is self-similarity" (Salat, 2012: 263).

Order and chaos are the two sides of the same coin (Triantakonstantis, 2012), and human beings always want to measure visual complexity. The fractal has been demonstrated to capture the visual patterns, these repeating patterns in finer and finer scales can be seen in mountain ranges, coast lines, clouds, rivers, trees, plants, and all beings in nature (Forsythe at al., 2011: 52). In addition to these, it is possible to talk about the existence of a hidden order and fractal geometry in every phenomenon that is thought to contain chaos, such as the realization cycle of meteorological events, economic predictions or the mutation of a cell. 
In his book "Fractal Cities" written in 1996, Michael Batty put forward the idea that fractal analysis can be used in cities as well (Mcadams, 2007:151). In urban studies fractals are used to analyze the urban form that is represented by the land use distribution and built-up patterns. Fractal dimensions take values between 1 and 2 and while higher values show a compact and homogeneous urban form with high complexity; lower values indicate low complexity or that the city is fragmented towards its periphery in the form of urban sprawl (Lagarias and Prastacos, 2017).

On the other sides, "lacunarity is a counterpart to the fractal dimension that describes the pattern of a fractal. It has to do with the size distribution of the holes. Roughly speaking, if a fractal has large gaps or holes, it has high lacunarity" (Rauch, 2019). While the fractal dimension quantifies how much space is occupied, on the other side the lacunarity is related to supplements how the space is occupied (Reiss at al., 2016). The word "lacuna" refers to a gap or pool and is derived from the word for "lake", in fractal analysis, lacunarity is more generally a measure of "visual texture" in images. Lacunarity usually denoted as $\Lambda$ or $\lambda$, and low lacunarity implies homogeneity and high lacunarity implies heterogeneity (Karperien et al., 2011). Applications of the Lacunarity coefficient can be seen in image processing, ecology, medicine, and other fields.

\section{Literature Review}

Applications of fractality and lacunarity coefficient can be seen in image processing, meteorology, medicine, neuroscience, ecology, architecture and many more fields. When the studies on cities with this method are examined, it is seen that some issues come to the fore. These issues can be summarized as follows.

- Research of architecture and nature simulations: Bovill measured the similarity between Amasya's coastline, landforms and traditional dwellings. Bovill's conclusion for Amasya that "the indigenous builders somehow applied the rhythms of nature to their housing site layout and elevation design" (Bovill, 1996; Vaughan and Ostwald, 2009).

- Measuring building facades and street silhouettes: In the book 'The Fractal Dimension of Architecture', the plans and facades of traditional, modern and postmodern houses were analyzed. While there is a decrease in plan and facade complexity from traditional to modern, minimalist plans have been found to have a higher complexity than expected (Ostwald and Vaughan, 2016). In another study, the visual layers such as form, material and ornament of the Süleymaniye Mosque facades were analyzed. It is understood that as the number of layers increases, the fractal value increases (Ediz and Ostwald, 2012).

- In the architectural design process: it was seen that experimental studies such as producing new construction variations compatible with the fractal value of the surrounding urban pattern in the computer environment were carried out (Ediz and Çağdaş, 2005; Gözübüyük, 2007).

- Multifractal applications: The spatial structure of Beijing city of China was divided into three layers from the city center to the urban border consisting of residential areas and suburbs where the spatial pattern became irregular, and the multifractal structure was investigated (Chen and Wang, 2013).

- Spatial comparison of settlements and examination of temporal morphological change through fractal analysis is the most common field of study. 
Until the beginning of the 2000s, analyzes on paper with low-resolution maps presented rather primitive data. In these years, fractal dimensions of 20 large US cities have been calculated based on a box-counting technique and found that " $\mathrm{D}$ for the largest city, New York City, and the smallest city, Omaha being 1.7014 and 1.2778 respectively" (Shen 2002: 419). Analyzes were systematized with programs such as Fractalyse, HarFa, FracLac, Fractalopolis developed in the following years. Besides, the ability to access high-resolution maps of cities via satellite data has increased the reliability of numerical methods in morphology studies. While fractal and lacunarity calculations are made; it is a fact that the methods and parameters used, the map resolution and the scope of the analysis area affect all results (Vaughan and Ostwald, 2009; Prastacos et al., 2017).

In a study, the urban sprawl of Istanbul between 1975 and 2005 was investigated over city stains in five temporal periods. The sprawl of the city along the coast was measured by the decrease in fractal dimension and the increase in the sprawl index between 1995 and 2005 (Terzi and Kaya, 2011).

Lagarias and Prastacos (2017) made the fractal calculation of 13 cities with a population of over 1 million, selected from Spain, Portugal and Greece. Differently, the land-use density (as \%) is expressed in grayscale maps of the built-up pattern. As a findings of the analysis; "fractal dimensions are not related to the area-wide percent distribution of built-up densities, but to the spatial distribution of built-up areas and associated densities." In this study, the all urban and rural built-up pattern of the city within its larger boundaries is also analyzed; the size of the larger urban zone (LUZ) area also greatly affected the results. While Oporto, Rome, Naples, Milan and Lisboa, whose built texture occupies the largest area in LUZ area, the highest fractal values are seen; although cities such as Bilbao, Turin, Sevilla and Thessaloniki have a compact built-up pattern, their fractal values are also decreasing due to the low area they occupy in the LUZ area (Lagarias and Prastacos, 2017). Fractal dimensions are found to be highly correlated to the average built-up density of the urban area and the percentage of the land that is developed (artificial area) (Lagarias and Prastacos, 2018).

In another study, the DNA of the city was investigated by numerical analysis of city sections of $1 \mathrm{~km} \times 1 \mathrm{~km}$ taken in the northwest-southeast axis of Istanbul. It has been found that the urban pattern in Istanbul has an irregular and heterogeneous character that does not increase or decrease steadily from the center to the periphery. The complexity level increases with the age of the urban pattern, usually approaching 1.7 (Kaya and Bölen, 2017).

In another temporal and spatial morphological study, the development of Bursa between 19392019 on an urban scale was investigated over seven city maps; fractal and lacunarity analyzes of 2006-2019 maps of nine sub-areas with different urban locations at regional scale were made. Looking at all values, it was seen that similar processes were experienced in different scales of the urban texture (fractal dimensions increased, lacunarity coefficients decreased) (Illhan and Ediz, 2019). 


\section{AN APPLICATION FOR TURKISH CITIES}

One of the most discussed issues in this chapter was the definition of urban boundaries. In 2012 after the Law No. 6360 enacted, as of 2014, the number of metropolitan in Turkey increased from sixteen to thirty, many villages and rural settlements have earned the status of neighborhoods of metropolitan cities. Some uncertainties in the process between rural and urban areas are still discussed (Kaya and Dökmeci, 2017:132).

In this study, urban macro boundaries are determined as the central districts of the provinces and the whole pattern that shows the "city" feature by combining with these districts. In order to reveal the spread of rapidly growing metropolises, the urban pattern is included in the analysis as a whole. On the other hand, rural settlements and industrial areas that have no physical connection with the city are excluded from the map borders.

In this context, "road network" maps, all of which were prepared by the authors, reflecting the urban pattern character in the most detailed and reliable way were used. The maps recorded from Google Maps satellite data belong to March 31, 2020 (Url 3) were transformed into binary maps ready for analysis, in which the road network is represented by black pixels and the background by white pixels. Map records were made to cover the equal level of detail in the urban pattern $(1 \mathrm{~km}$ urban area $35 \mathrm{~mm}, 132$ pixels, approximately $1 / 28.570$ scale). Therefore, the maps of large-size metropolises such as Istanbul, Ankara, Izmir, Bursa, Adana and large-medium-sized cities were obtained by combining many urban parts recorded at the same scale in digital environment.

Fractal dimension and lacunarity value are variables that can be measured by the distribution ratio of filled and empty pixels on the paper. Considering the sample size, it was questioned many times how to represent 81 cities of different sizes in the most accurate way in a two-dimensional environment during the preparation for the analysis. The following determinations was made in many experimental analyzes:

When all cities represented on a fixed background of the same dimensions since medium and especially small-size cities of the same scale occupy less area than large-size megacities, the analysis results are predictable in a way that no comparison can be made between provinces. In general, $\mathrm{Fb}$ values of small-size cities are lower and Lac values are higher. On the other hand, as long as the detail level of large-size city maps, pattern boundaries included in the map and map ratios are preserved, it has been determined that fractal and lacunarity values depending on occupancy and space ratios remain almost the same. For example, for the city of Istanbul, Fd: 1.7159, Lac: 0.819 values were calculated from the map with 2976x1890 pixels prepared at 300 dpi resolution; Fd: 1.7199, Lac: 0.8041 values were obtained from the same map with 1488x945 pixels.

As a result of all these experiments, all maps were represented on a background with an optimum resolution of $1488 \times 945$ pixels and 300 dpi. Medium and small-size cities that make up the majority of the sample were mapped without changing their scale. On the other hand large-size cities were downsized at the same rate. 
Image-J program and FracLac plugin were used for all calculations. ImageJ is an open source image processing program designed for scientific multidimensional images. FracLac is a plugin for ImageJ, and has evolved to a suite of fractal analysis and morphology functions (Karperien, 19992003). For fractal dimension the most commonly used box-counting method when performing fractal analysis of complex tissues was preferred and lacunarity was automatically calculated during box counting scan.

In the box-counting method, the binary image, in which are represented the fullnesses with black and the spaces with white, is overlaid with a grid with different box sizes in each iteration. The number of filled boxes with data in calculated every two iteration and the logarithmic ratio of the box size change of the grid coincident with the map gives the box counting fractal dimension $\left(\mathrm{D}_{\mathrm{B}}\right)$ (Ediz and Ostwald, 2012).

Equation 1. Calculation of fractal dimension in box counting method.

$$
\mathrm{D}_{\mathrm{B}(1-2)}=\left[\log \left(\mathrm{N}_{(\mathbf{S} 2)}\right)-\log \left(\mathrm{N}_{(\mathrm{S} 1)}\right)\right] /\left[\log \left(1 / \mathrm{S}_{2}\right)-\log \left(1 / \mathrm{S}_{1}\right)\right]
$$

In Equation 1; $\mathrm{N}_{(\mathrm{S} 2)}$ : The number of boxes containing data in the next iteration; $\mathrm{N}_{\left(\mathrm{S}_{1}\right)}$ : Number of boxes with data in the previous iteration; $1 / S_{2}$ : Box size in the next iteration; $1 / S_{1}$ : Box size in the previous iteration.
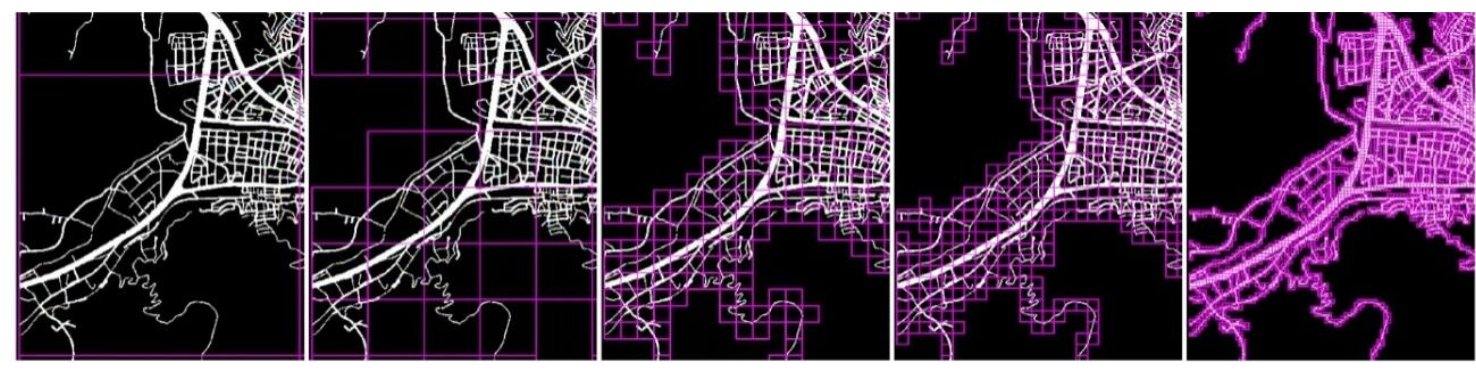

Figure 1. An example of the scanning stages of a map analyzed by the box-counting method of FracLac plugin.

One of the advantages of FracLac is that it automatically adjusts the number of iterations after the maximum and minimum box sizes are defined according to the method of scanning the image. In the calculations made in this study, as the box-counting scanning method relative sizes which means integer factors of the largest box was determined; the maximum box size as $45 \%$ of the map; min box size as $0 \%$ for the program to automatically determine the meaningful smallest box size were defined (A grid size string is obtained in pixels, such as 2, 4, 8, 16, 32, 64, 128, 256, 512). Figure 1 shows five iterations of the map scanned with different box sizes that FracLac automatically determines in the box-counting method. Another advantage of the plugin is that each map is scanned with the specified number of grid positions in the program and the weighted average of the obtained values is the main value. In this study, each measurement was made with four different grid positions. In addition to fractal dimension and lacunarity coefficients of cities, 2018 demographic data and 2018 gross domestic product per capita by provinces are seen in Table 1. 
While fractal and lacunarity values are obtained through the urban macroform limited to urban settlements, per capita GDP and population data are at the province level.

Table 1. Fractal dimensions and lacunarity of Turkish cities.

\begin{tabular}{|c|c|c|c|c|}
\hline Cities & $\begin{array}{l}\text { Fractal } \\
\text { dimension }\end{array}$ & Lacunarity & $\begin{array}{l}\text { GDP per capita } \\
2018 \text { (dolar) }\end{array}$ & Population 2018 \\
\hline Adana & 1,7299 & 0,7139 & 7083 & 2220125 \\
\hline Adiyaman & 1,5652 & 0,9163 & 4632 & 624513 \\
\hline Afyon & 1,5918 & 0,7760 & 6359 & 725568 \\
\hline Ăgrn & 1,5545 & 0,7668 & 3301 & 539657 \\
\hline Amasya & 1,5813 & 0,6723 & 6805 & 337508 \\
\hline Ankara & 1,7708 & 0,8134 & 12690 & 5503985 \\
\hline Antalya & 1,7308 & 0,6701 & 9496 & 2426356 \\
\hline Artvin & 1,5594 & 0,5506 & 8001 & 174010 \\
\hline Aydin & 1,6076 & 0,8755 & 6919 & 1097746 \\
\hline Balikesir & 1,6256 & 0,8282 & 8004 & 1226575 \\
\hline Bilecik & 1,4220 & 0,9464 & 10630 & 223448 \\
\hline Bingöl & 1,5905 & 0,6911 & 4685 & 281205 \\
\hline Bitlis & 1,3425 & 0,6702 & 3926 & 349396 \\
\hline Bolu & 1,6170 & 0,7198 & 9886 & 311810 \\
\hline Burdur & 1,6006 & 0,8138 & 7928 & 269926 \\
\hline Bursa & 1,7113 & 0,6310 & 10789 & 2994521 \\
\hline Çanakkale & 1,4771 & 1,0449 & 9484 & 540662 \\
\hline Çankırı & 1,3899 & 0,9323 & 5926 & 216362 \\
\hline Çorum & 1,5982 & 0,9189 & 6120 & 536483 \\
\hline Denizli & 1,6926 & 0,8669 & 8939 & 1027782 \\
\hline Diyarbakır & 1,6122 & 0,8014 & 4523 & 1732396 \\
\hline Edirne & 1,6664 & 0,5930 & 7800 & 411528 \\
\hline Elazığ & 1,6403 & 0,6260 & 6095 & 595638 \\
\hline Erzincan & 1,6193 & 0,7033 & 7893 & 236034 \\
\hline Erzurum & 1,5918 & 0,7747 & 5832 & 767848 \\
\hline Eskişehir & 1,6757 & 0,8016 & 9959 & 871187 \\
\hline Gaziantep & 1,6863 & 0,9271 & 6916 & 2028563 \\
\hline Giresun & 1,6298 & 0,6012 & 5488 & 453912 \\
\hline Gümüşhane & 1,4580 & 0,7258 & 5587 & 162748 \\
\hline Hakkari & 1,5099 & 1,0455 & 4351 & 286470 \\
\hline Hatay & 1,6446 & 0,7631 & 6352 & 1609856 \\
\hline Isparta & 1,6426 & 0,8962 & 7434 & 441412 \\
\hline Mersin & 1,6884 & 0,8108 & 7724 & 1814468 \\
\hline İstanbul & 1,7199 & 0,8041 & 16261 & 15067724 \\
\hline Izmir & 1,5857 & 1,0232 & 11220 & 4320519 \\
\hline Kars & 1,4467 & 0,7954 & 5055 & 288878 \\
\hline Kastamonu & 1,4892 & 0,9079 & 7055 & 383373 \\
\hline Kayseri & 1,6959 & 0,6835 & 8162 & 1389680 \\
\hline Kırklareli & 1,6118 & 0,8032 & 9637 & 360860 \\
\hline Kırşehir & 1,4806 & 1,0879 & 6554 & 241868 \\
\hline Kocaeli & 1,7431 & 0,4450 & 15753 & 1906391 \\
\hline Konya & 1,6939 & 0,8075 & 7444 & 2205609 \\
\hline Kütahya & 1,6304 & 0,8753 & 7089 & 577941 \\
\hline Malatya & 1,6637 & 0,7105 & 5665 & 797036 \\
\hline
\end{tabular}




\begin{tabular}{|c|c|c|c|c|}
\hline \multicolumn{5}{|l|}{ Table 1 continues... } \\
\hline Cities & $\begin{array}{l}\text { Fractal } \\
\text { dimension }\end{array}$ & Lacunarity & $\begin{array}{l}\text { GDP per capita } \\
2018 \text { (dolar) }\end{array}$ & Population 2018 \\
\hline Manisa & 1,6683 & 0,9277 & 8868 & 1429643 \\
\hline Kahramanmaraş & 1,6854 & 0,9264 & 5718 & 1144851 \\
\hline Mardin & 1,4889 & 0,7904 & 4780 & 829195 \\
\hline Muğla & 1,6154 & 0,6408 & 9071 & 967487 \\
\hline Muş & 1,5703 & 0,7452 & 4183 & 407992 \\
\hline Nevşehir & 1,6428 & 0,9903 & 6444 & 298339 \\
\hline Niğde & 1,6183 & 0,6233 & 6149 & 364707 \\
\hline Ordu & 1,6474 & 0,7308 & 5402 & 771932 \\
\hline Rize & 1,5721 & 0,7619 & 7732 & 348608 \\
\hline Sakarya & 1,6521 & 0,8160 & 8832 & 1010700 \\
\hline Samsun & 1,6874 & 0,7403 & 6740 & 1335716 \\
\hline Siirt & 1,5630 & 0,7235 & 4101 & 331670 \\
\hline Sinop & 1,5587 & 0,5851 & 5634 & 219733 \\
\hline Sivas & 1,6280 & 0,8047 & 6635 & 646608 \\
\hline Tekirdağ & 1,6333 & 0,8027 & 11455 & 1029927 \\
\hline Tokat & 1,6271 & 0,8377 & 5013 & 612646 \\
\hline Trabzon & 1,6826 & 0,6075 & 7614 & 807903 \\
\hline Tunceli & 1,4581 & 0,7713 & 7982 & 88198 \\
\hline Şanliurfa & 1,6185 & 0,8659 & 3459 & 2035809 \\
\hline Uşak & 1,6194 & 0,8907 & 7057 & 367514 \\
\hline Van & 1,6189 & 0,7053 & 3550 & 1123784 \\
\hline Yozgat & 1,5650 & 0,7299 & 5726 & 424981 \\
\hline Zonguldak & 1,6866 & 0,4578 & 6931 & 599698 \\
\hline Aksaray & 1,5787 & 0,7917 & 6436 & 412172 \\
\hline Bayburt & 1,4856 & 0,8831 & 5853 & 82274 \\
\hline Karaman & 1,6364 & 0,7514 & 8658 & 251913 \\
\hline Kurıkkale & 1,6217 & 0,7183 & 9637 & 286602 \\
\hline Batman & 1,5971 & 0,9978 & 4124 & 599103 \\
\hline Şırnak & 1,4951 & 0,7275 & 6436 & 524190 \\
\hline Bartın & 1,5114 & 0,7376 & 5962 & 198999 \\
\hline Ardahan & 1,4890 & 0,5726 & 5882 & 98907 \\
\hline Iğdır & 1,6113 & 0,6903 & 5654 & 197456 \\
\hline Yalova & 1,6274 & 0,7683 & 10059 & 262234 \\
\hline Karabük & 1,6221 & 0,7528 & 7676 & 248014 \\
\hline Kilis & 1,6351 & 0,7605 & 5210 & 142541 \\
\hline Osmaniye & 1,6055 & 0,8052 & 5922 & 534415 \\
\hline Düzce & 1,7013 & 0,5467 & 8159 & 387844 \\
\hline
\end{tabular}

In Table 2, all fractal dimensions and lacunarity coefficients are listed, and the first and last 10 values are given. As known high fractal dimension implies high complexity, low fractal dimension implies low complexity. On the other side, low lacunarity implies homogeneity and high lacunarity implies heterogeneity. As seen in Table 2, the first cities in terms of fractal dimensions are located in the city ahead in terms of Turkey's economic and social development. Cities that are in the last ten according to their fractal dimensions are not economically and socially ahead. A striking point in Table 2 is that Izmir is not in the top ten in terms of fractal dimension, and is in the top ten in terms of lacunarity coefficient. It is also remarkable that Zonguldak and Kocaeli are the most homogeneous cities with the lowest lacunarity coefficients. 
Table 2. First 10 and last 10 values of fractal dimensions and lacunarity coefficients.

\begin{tabular}{|llll|}
\hline Cities & Fractal dimension & Cities & Lacunaritiy \\
\hline Ankara & 1,7708 & Kirşehir & 1,0879 \\
Kocaeli & 1,7431 & Hakkari & 1,0455 \\
Antalya & 1,7308 & Çanakkale & 1,0449 \\
Adana & 1,7299 & Izmir & 1,0232 \\
İstanbul & 1,7199 & Batman & 0,9978 \\
Bursa & 1,7113 & Nevşehir & 0,9903 \\
Düzce & 1,7013 & Bilecik & 0,9464 \\
Kayseri & 1,6959 & Çankirı & 0,9323 \\
Konya & 1,6939 & Manisa & 0,9277 \\
Denizli & 1,6926 & Gaziantep & 0,9271 \\
$\ldots$ & $\ldots$ & $\ldots$ & $\ldots$ \\
$\ldots$ & $\ldots$ & $\ldots$ & $\ldots$ \\
$\ldots$ & $\ldots$ & $\ldots$ & $\ldots$ \\
Mardin & 1,4889 & Niğde & 0,6233 \\
Bayburt & 1,4856 & Trabzon & 0,6075 \\
Kirşehir & 1,4806 & Giresun & 0,6012 \\
Çanakkale & 1,4771 & Edirne & 0,5930 \\
Tunceli & 1,4581 & Sinop & 0,5851 \\
Gümüşhane & 1,4580 & Ardahan & 0,5726 \\
Kars & 1,4467 & Artvin & 0,5506 \\
Bilecik & 1,4220 & Düzce & 0,5467 \\
Çankırı & 1,3899 & Zonguldak & 0,4578 \\
Bitlis & 1,3425 & Kocaeli & 0,4450 \\
\hline
\end{tabular}

When looking at the pattern of cities in Turkey, said that the urban cores develop along the main axes or coastline. It is seen that the industrial zones, suburbs and surrounding villages established on the outer side of the city have been included in the city borders over time. Thus, multi-centered big cities are formed and the spread of the urban pattern gradually differing from its original form depending on the sprawling on macro scale. Cities such as Tekirdağ, Mersin, İstanbul, Samsun and Izmir can be given as examples of large and crowded cities that have sprawling along the coast. Since Izmir is sprawled more along both the coastline and main axes, the fractal size of the map, where the stacked pattern is represented, is quite low.

Table 3 shows the descriptive statistics of fractal dimensions and lacunarity coefficients. As it can be seen in Figure 2, fractal dimensions of the Turkish cities are not distributed normally. Also it was determined from probability plot that Bilecik, Bitlis and Çankır1 are outliers of fractal dimensions.

Table 3. Descriptive statistics of fractal dimensions and lacunarity coefficients.

\begin{tabular}{|l|l|l|l|l|l|l|l|l|l|l|}
\hline & $\mathrm{N}$ & Mean & SD & Min & Q1 & Median & Q3 & Max & Skewness & Kurtosis \\
\hline $\begin{array}{l}\text { Fractal } \\
\text { dimension }\end{array}$ & 81 & 1,6038 & 0,0835 & 1,3425 & 1,5651 & 1,6185 & 1,6579 & 1,7708 & $-0,77$ & 0,63 \\
\hline Lacunarity & 81 & 0,7754 & 0,1294 & 0,4450 & 0,7043 & 0,7713 & 0,8664 & 1,0879 & $-0,00$ & 0,21 \\
\hline
\end{tabular}




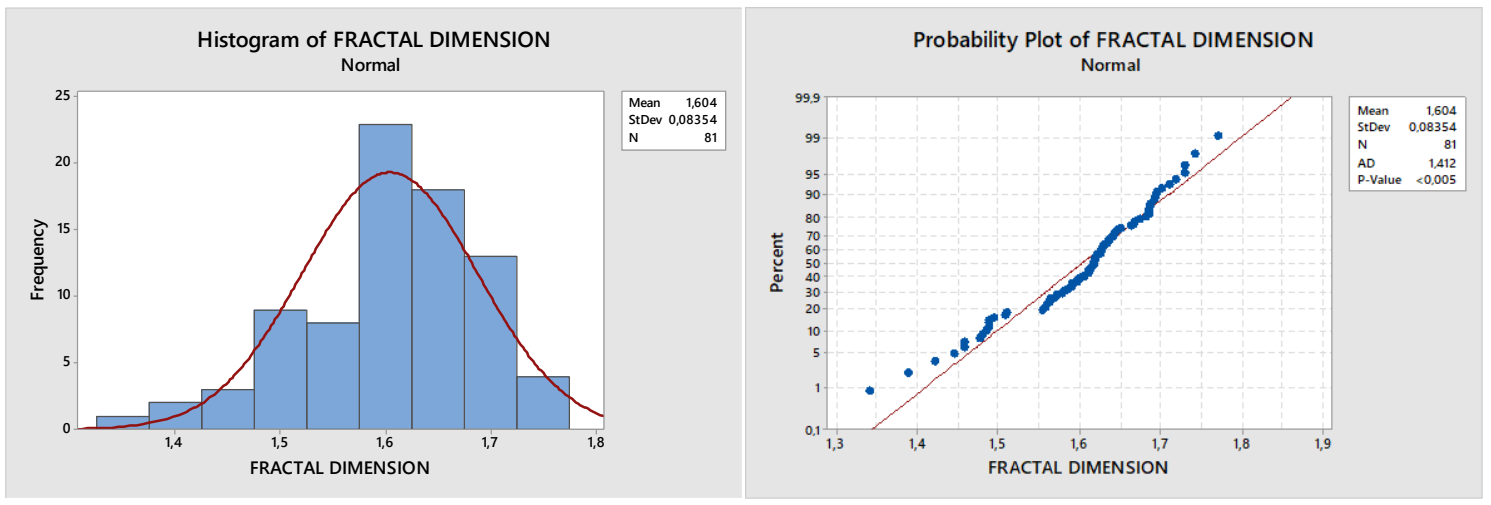

Figure 2. Histogram and probability plot of fractal dimensions.

The distribution of fractal dimensions is not a normal distribution and the shape of the histogram in Figure 2 raises the question of whether this distribution is two-mode distribution. As in Figure 3 , if we categorize fractal dimensions into two groups, such as above and below the mean, we get two-mode histograms.

However, an important question arises here. Why are the fractal dimensions of Turkish cities in two groups? When we look at both groups in which the fractal dimension results obtained in Table 1 are distributed, we can see that those above the average are economically and socially better. It should be added that this result is an exception like Izmir.

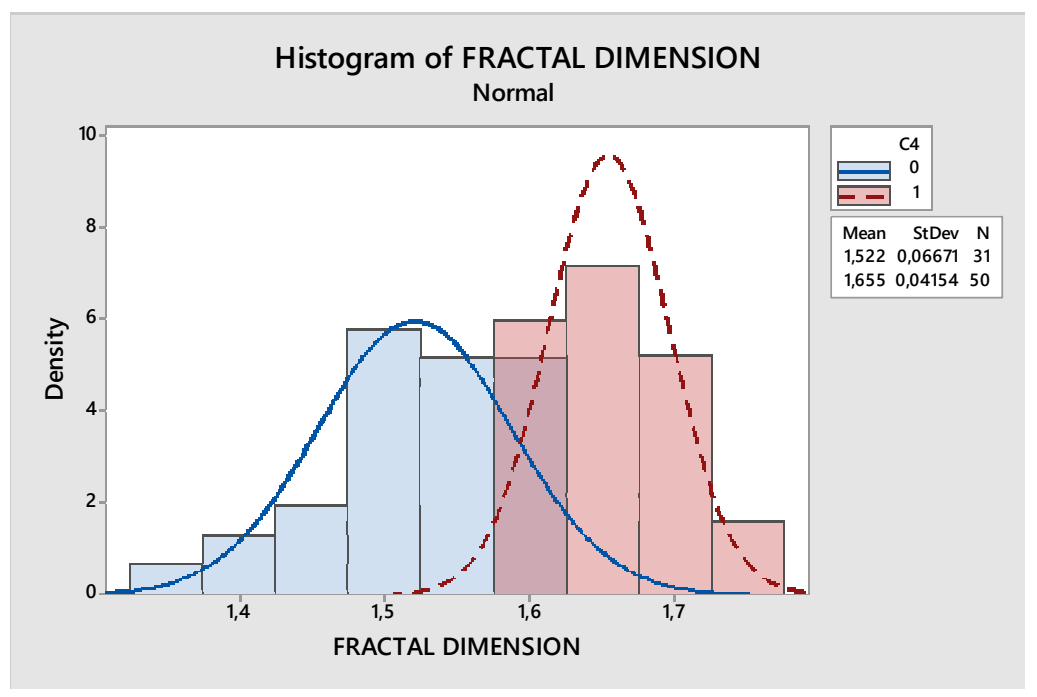

Figure 3. Two-modeness of fractal dimensions.

This time, if we examine the Figure 4 created for the lacunarity coefficients, we can say that these coefficients are normally distributed and that Kocaeli and Zonguldak are the outliers of this distribution. Another striking point is that in both the distribution of fractal dimensions and the distribution of the lacunarity coefficients, outliers are observed always in the tail with low values. Table 4 shows us the relationships between our variables. 


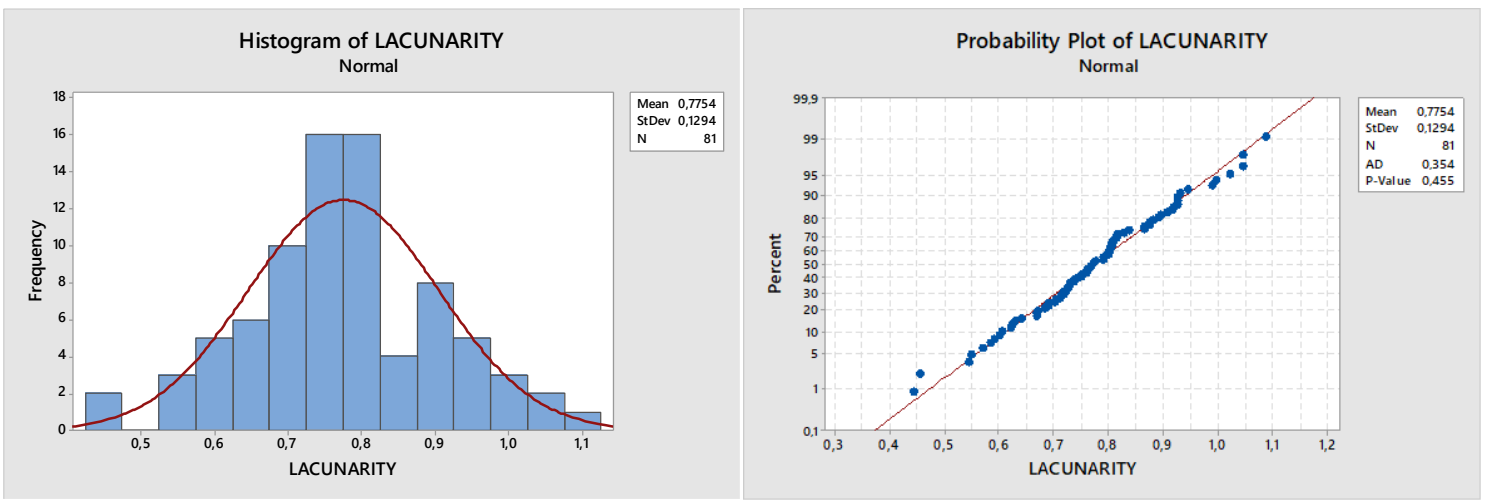

Figure 4. Histogram and probability plot of lacunarity coefficients.

Table 4. Correlation coefficients of variables.

\begin{tabular}{|l|l|l|l|l|}
\hline & Fractal dimension & Lacunarity & Population & Income per capita \\
\hline Fractal dimension & 1,000 & $-0,255\left(\mathrm{p}=0,021^{*}\right)$ & $0,389\left(\mathrm{p}=0,000^{* *}\right)$ & $0,412\left(\mathrm{p}=0,000^{* *}\right)$ \\
\hline Lacunarity & & 1,000 & $0,062(0,585)$ & $-0,082(0,464)$ \\
\hline Population & & & 1,000 & $0,550\left(\mathrm{p}=0,000^{* *}\right)$ \\
\hline Income per capita & & & & 1,000 \\
\hline
\end{tabular}

"Some people say, that these two measures should be complementary, i.e. where one decreases, second may increase... We did experiments on this idea, and it appears, that such conclusion is met in many cases" (Borys, 2009: 1487). Similarly, it has been seen in our results that, there is a weak, negative, significant ( $5 \%$ significance level) correlation between fractal dimension and lacunarity. Considering that the average fractal dimension of cities in Turkey is 1.60; it can be said that they are generally compact cities. Therefore, the lacunarity coefficient, which is the complementary variable of the fractal dimension, has been quite effective when grouping cities. There are several reasons why the negative correlation between these two variables, which is expected to be at a higher significance level, appears at a low significance level. The gapped extension of the large-sized cities with fractal dimensions above the average towards the periphery of the city causes the lacunarity value to increase. Besides, the lacunarity values can be high due to the linear developing structure of the coastal settlements whose fractal values are average and above.

Also in our study, a weak, positive, significant (1\% significance level) relationship between fractal dimension and population; and a moderate, positive significant (1\% significance level) relation between fractal dimension and income per capita have been found. Besides, no significant relationship was found between lacunarity and population (Figure 5). These results may be due to the different scope of the data. For example: In a large-size city like Istanbul, which includes many sectors (industry, commerce, service, technology, tourism, etc.) in terms of economic income, the majority of the population is concentrated in urban areas. In a smaller size province like Muğla, whose economic returns depend on sectors such as agriculture, animal husbandry and summer tourism, the population is distributed more homogeneously to different districts. On the other 
hand, in most provinces, especially in middle and eastern provinces, income is generated in noncentral districts. The low level of significance between the demographic and economic data at the provincial level and the F and Lac values measured on the urban macroform can be explained in this way.

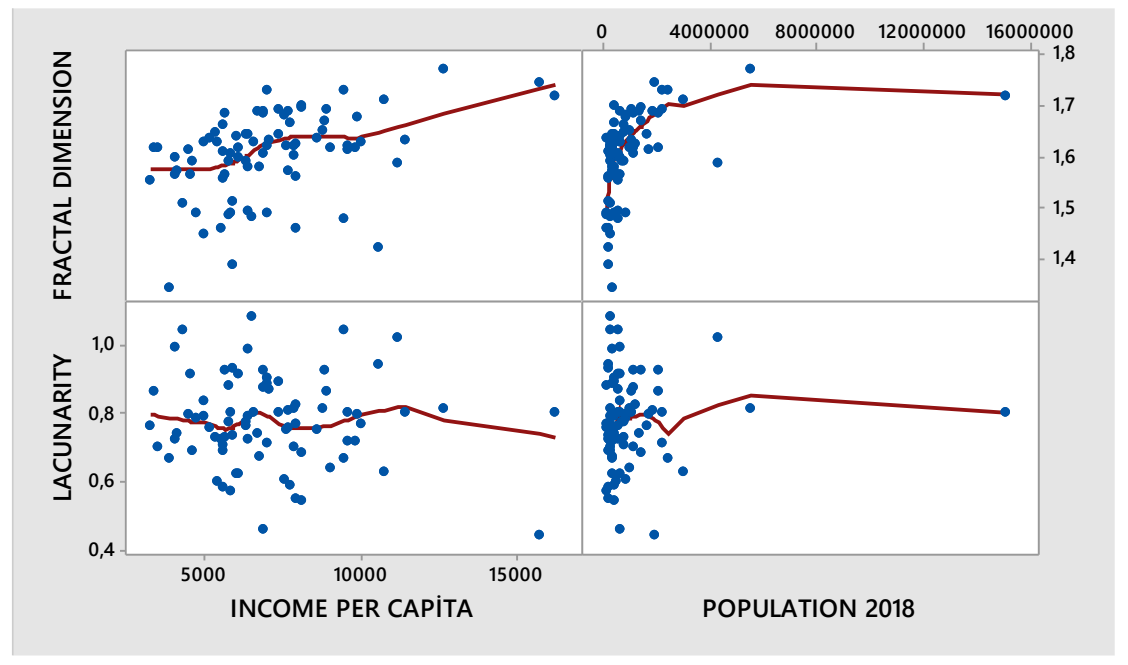

Figure 5. Correlation matrix: Income per capita, fractal dimension, lacunarity and population 2018.

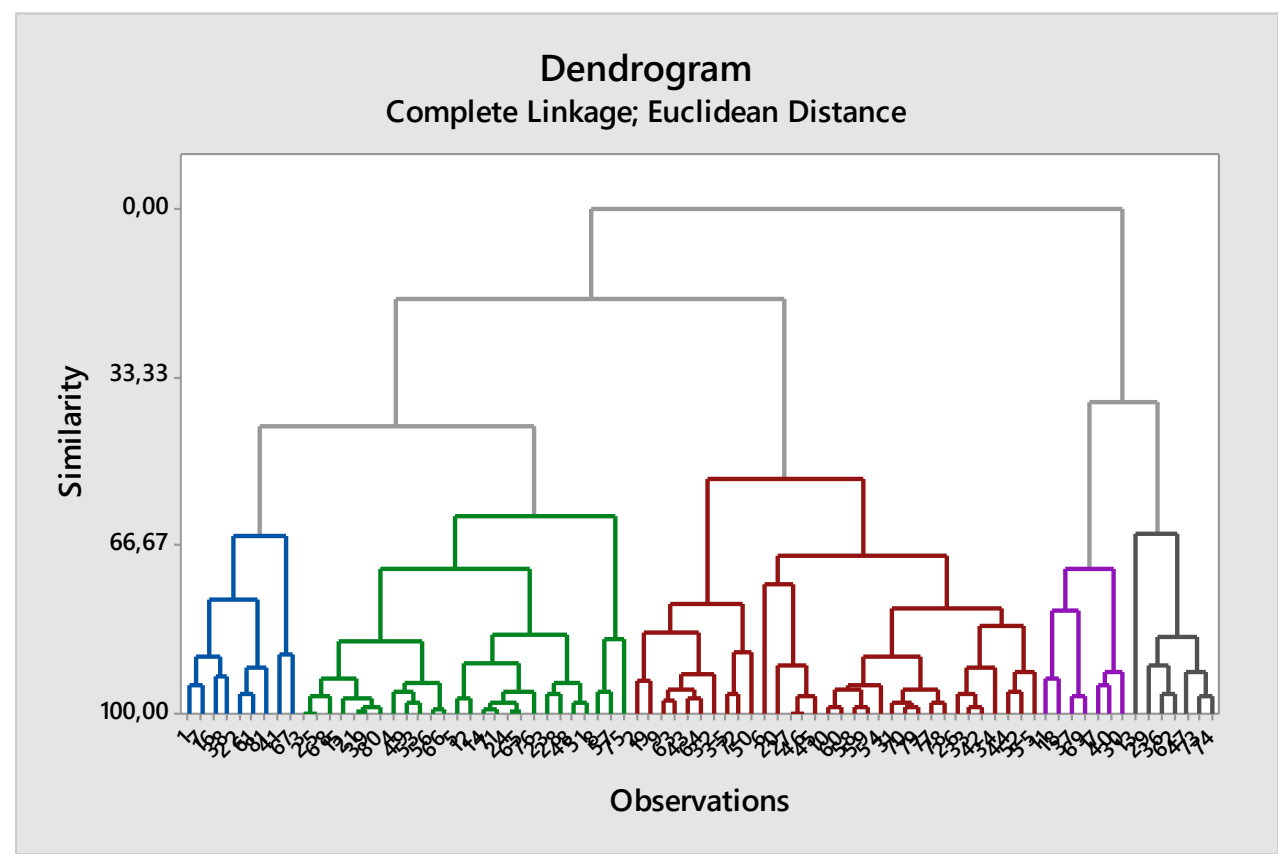

Figure 6. Dendogram of Turkish cities.

In this part of the application, there will be found the clusters of Turkish cities in a multivariate context, considering two variables such as fractal dimensions and lacunarity coefficients. Figure 8 shows the dendogram obtained in this way. Since it is difficult to see the numbers of the cities in Figure 6, the same dendogram is given in Figure 7 and Figure 8 in two separate parts. 


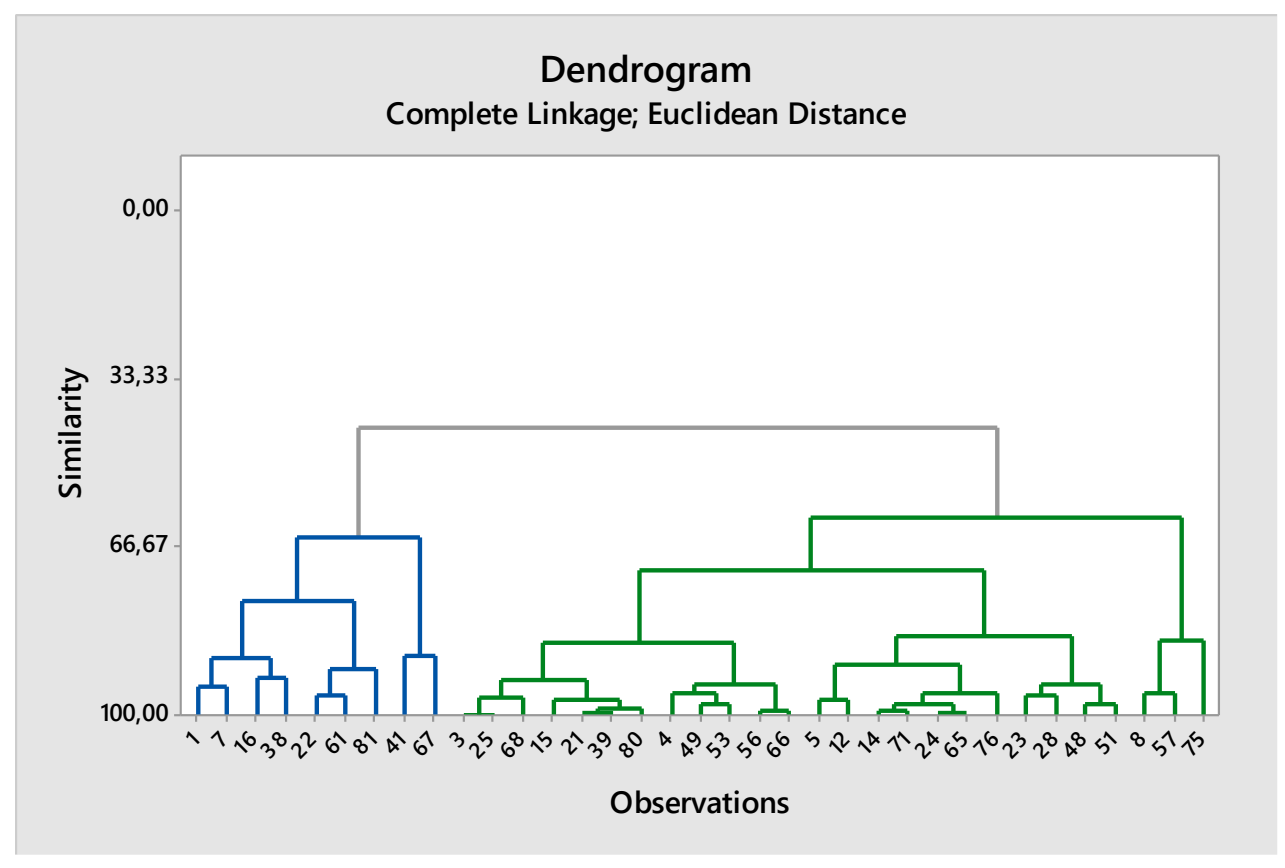

Figure 7. Dendogram of Turkish cities (Part I).

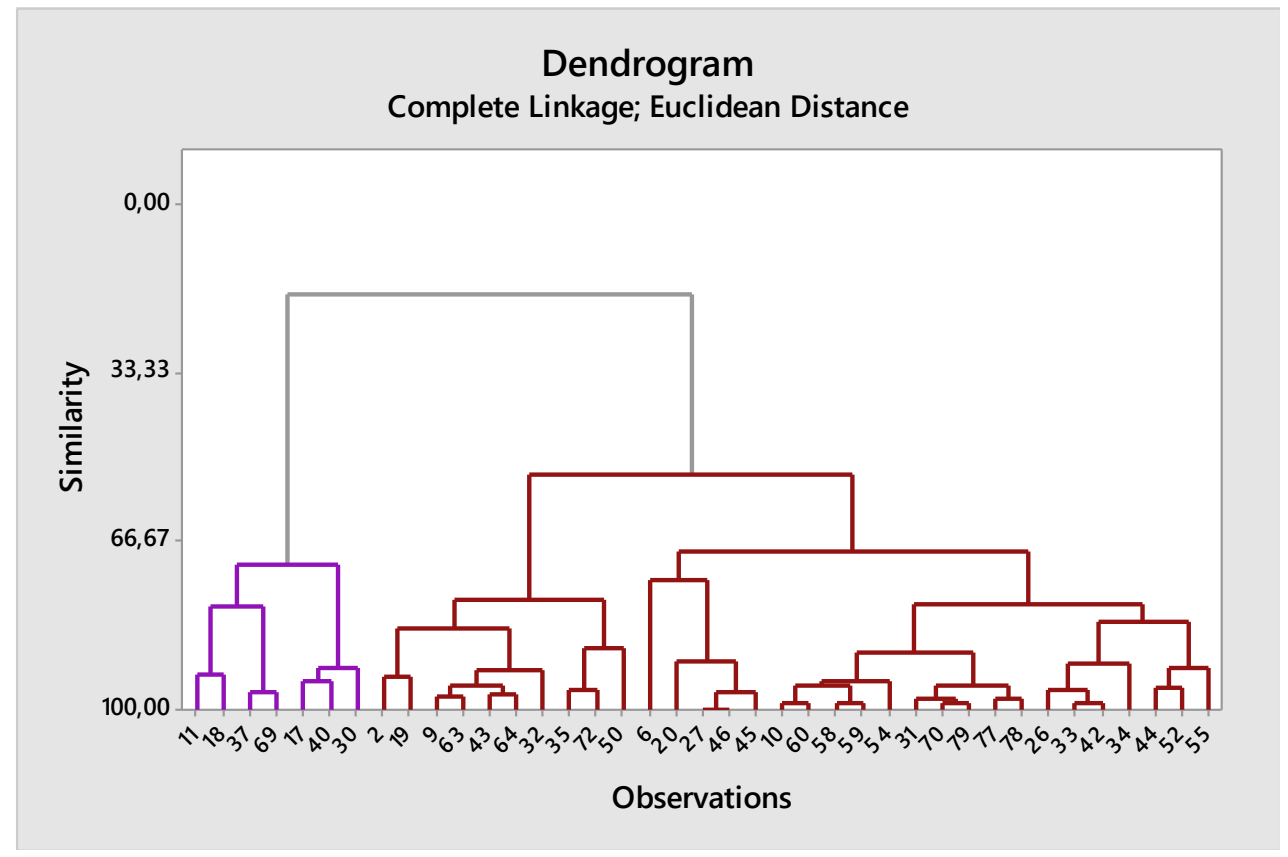

Figure 8. Dendogram of Turkish cities (Part II).

Also, the results of the dendogram as the city name can be seen in Table 5. In Table 5, the city names with grey shades are more similar to each other in the context of the two variables. In the next figures, the cities in the same cluster are shown together and more similar urban patterns are marked. 
Table 5. Clusters of Turkish cities.

\begin{tabular}{|c|c|c|c|c|c|c|c|c|}
\hline Cluster 1 & Cluster 2 & Cluster 3 & Cluster 4 & Cluster 5 & Cluster 6 & Cluster 7 & Cluster 8 & Cluster 9 \\
\hline Adana & Afyon & Amasya & \multirow{12}{*}{$\begin{array}{l}\text { Artvin } \\
\text { Sinop } \\
\text { Ardahan }\end{array}$} & Bilecik & Adiyaman & Ankara & Balıkesir & Eskişehir \\
\hline Antalya & Erzurum & Bingöl & & Çankırı & Çorum & Denizli & Tokat & Mersin \\
\hline Bursa & Aksaray & Bolu & & Kastamonu & Aydin & Gaziantep & Sivas & Konya \\
\hline Kayseri & Burdur & Kirikkale & & Bayburt & Şanlıurfa & Kahramanmaraş & Tekirdağ & İstanbul \\
\hline Edirne & Diyarbakır & Erzincan & & Çanakkale & Kütahya & Manisa & Karaman & Malatya \\
\hline Trabzon & Kurklareli & Van & & Kirşehir & Uşak & & Kilis & Ordu \\
\hline Düzce & Osmaniye & Iğdır & & Hakkari & Isparta & & Sakarya & Samsun \\
\hline Kocaeli & Ağrn & Elaz1ğ & & & İzmir & & Hatay & \\
\hline \multirow[t]{4}{*}{ Zonguldak } & Muş & Giresun & & & Batman & & Yalova & \\
\hline & Rize & Muğla & & & Nevşehir & & & \\
\hline & Siirt & & & & & & & \\
\hline & & & & & & & & \\
\hline
\end{tabular}

If we evaluate the groups one by one; while the fractal dimensions of the cities in Cluster 1 are above the average and close to the maximum value, lacunarity $(\mathrm{Lac})$ values have below the average, hence they have dense and less void textures (Figure 9). Both fractal and Lac values of cities in Cluster 2 are approximately average. These cities are generally single-center, medium and small-size cities. The patterns of the cities of Afyon-Erzurum and Diyarbakır-Kırklareli, which are marked in Figure 10, are more similar structures according to these two values. 


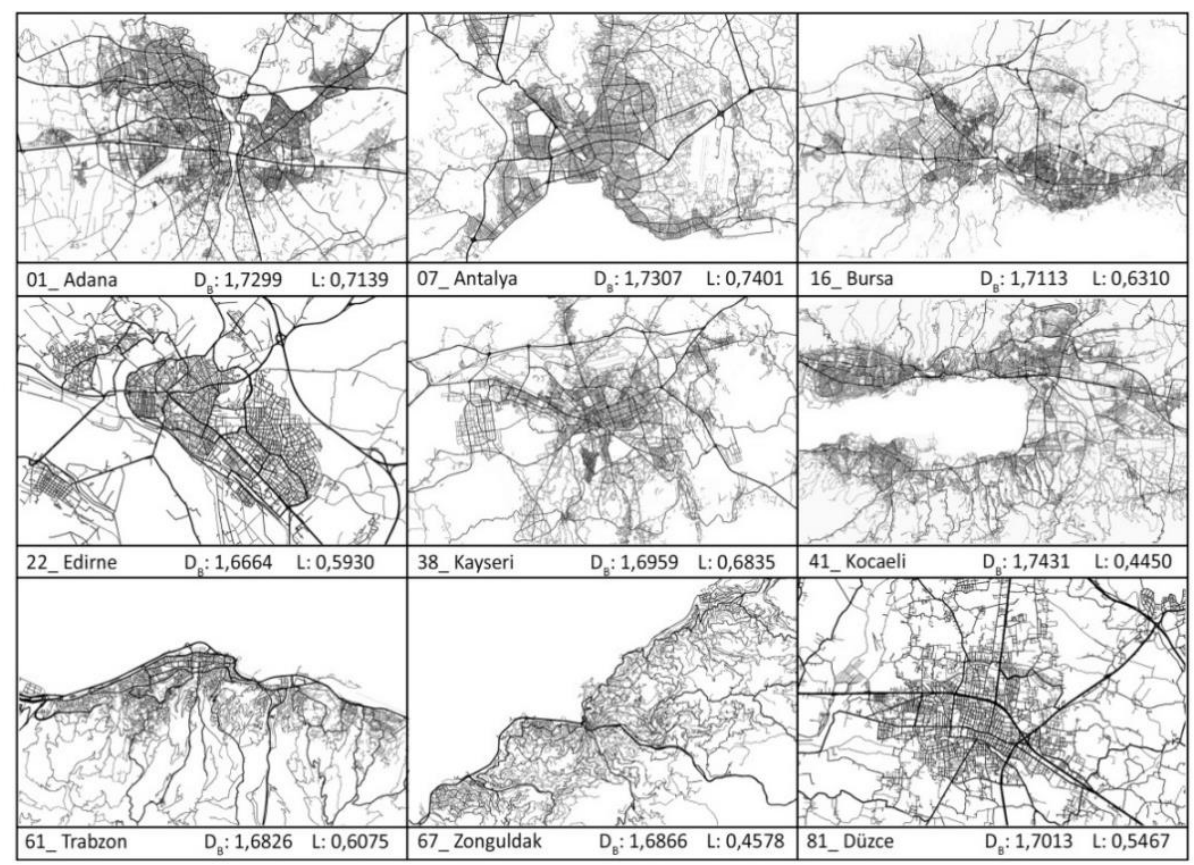

Figure 9. Cities in Cluster 1.

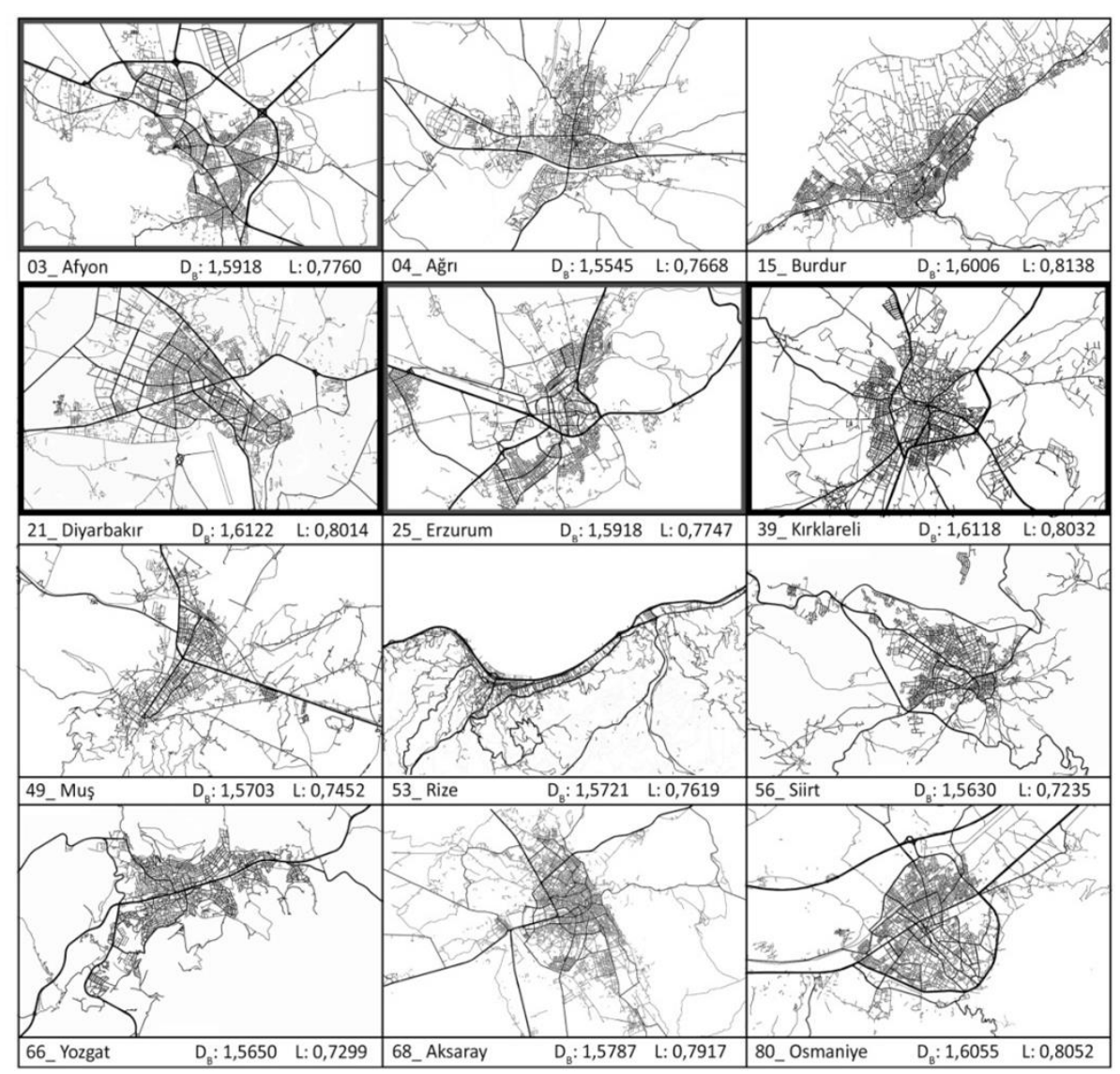

Figure 10. Cities in Cluster 2. 


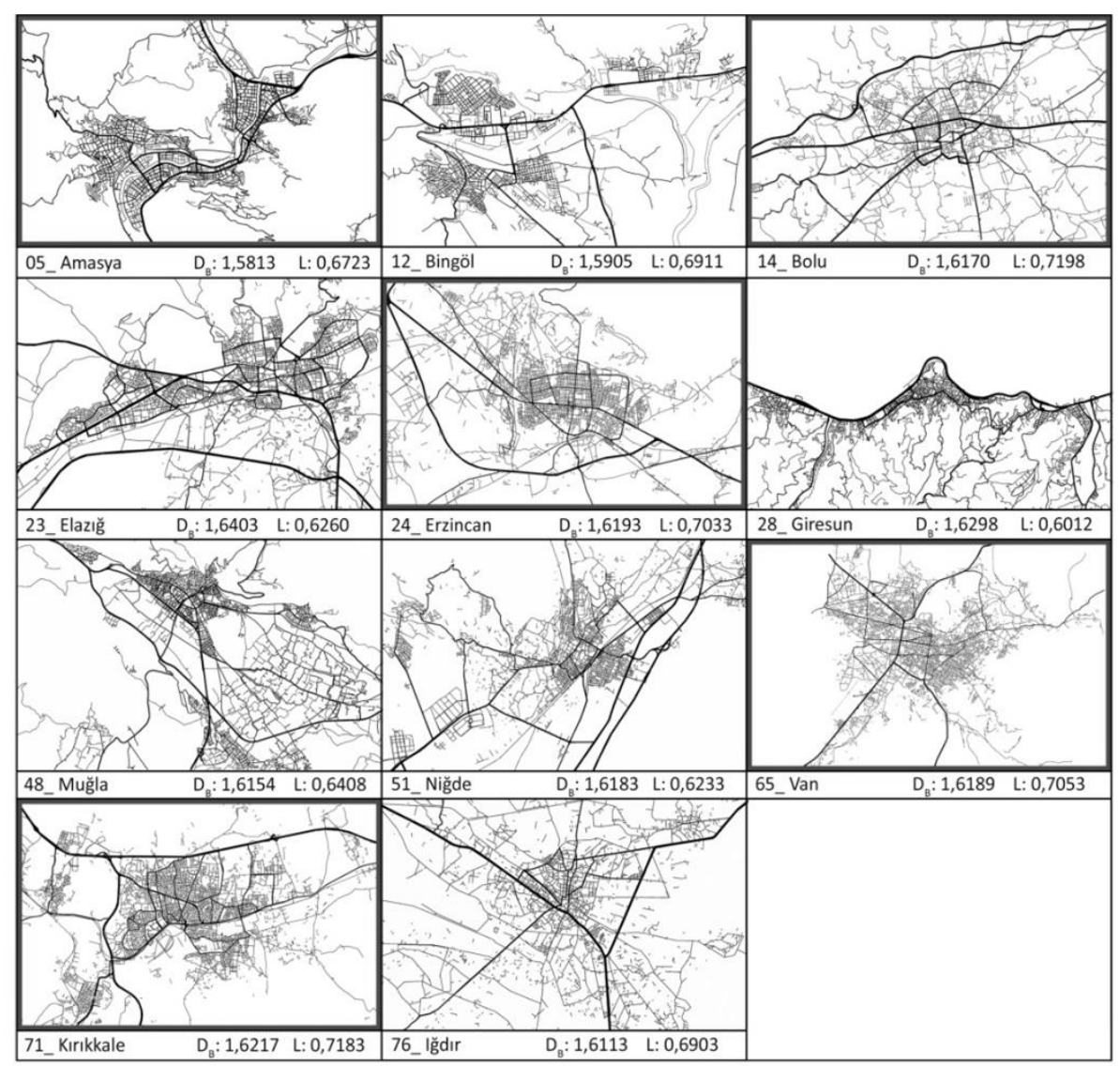

Figure 11. Cities in Cluster 3.

While the $\mathrm{D}_{\mathrm{B}}$ values of the cities in Cluster 3 are average and just below, Lac values are below the average. It can be said that these provinces are clustered around a homogeneous and single center (Figure 11). $\mathrm{D}_{\mathrm{B}}$ and Lac values of the cities in Cluster 4 are below average. Although the urban textures in the cluster are not physically similar, they are similar in terms of hollow structure and hierarchy (Figure 12). The $\mathrm{D}_{\mathrm{B}}$ values of the cities in Cluster 5 are at the lowest values in the whole cities and the Lac values at the highest and close to maximum value. These are small-size and lowpopulation provinces (Figure 13). While the $\mathrm{D}_{\mathrm{B}}$ values of the cities in Cluster 6 are at an average level, Lac is above average. Apart from İzmir, can be said that the cities in this cluster developed around a single homogeneous center and along main axes. Cities other than İzmir and Şanliurfa are medium and small-size cities. Physical similarities between urban patterns are shown in Figure 14.

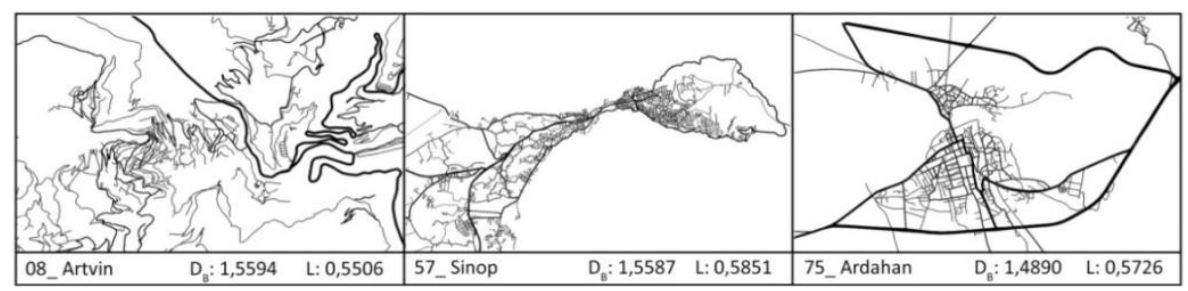

Figure 12. Cities in Cluster 4. 


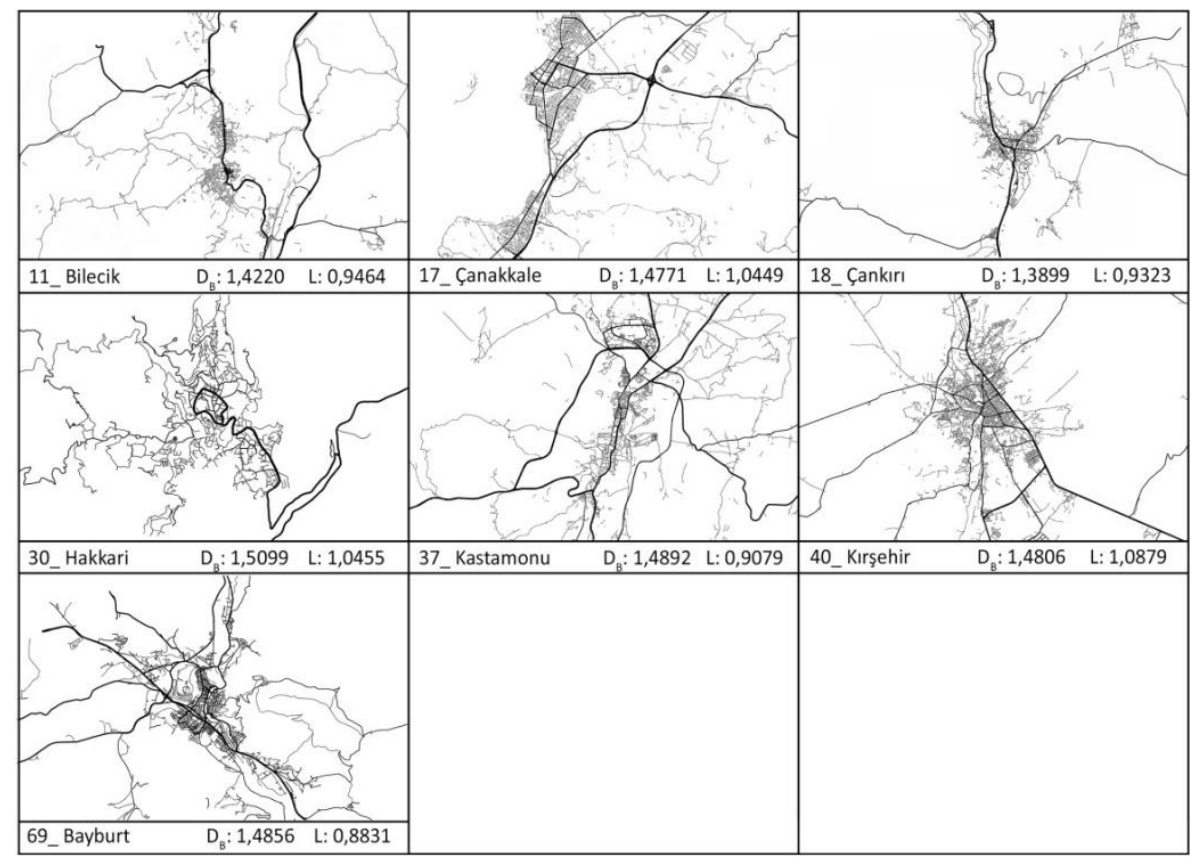

Figure 13. Cities in Cluster 5.

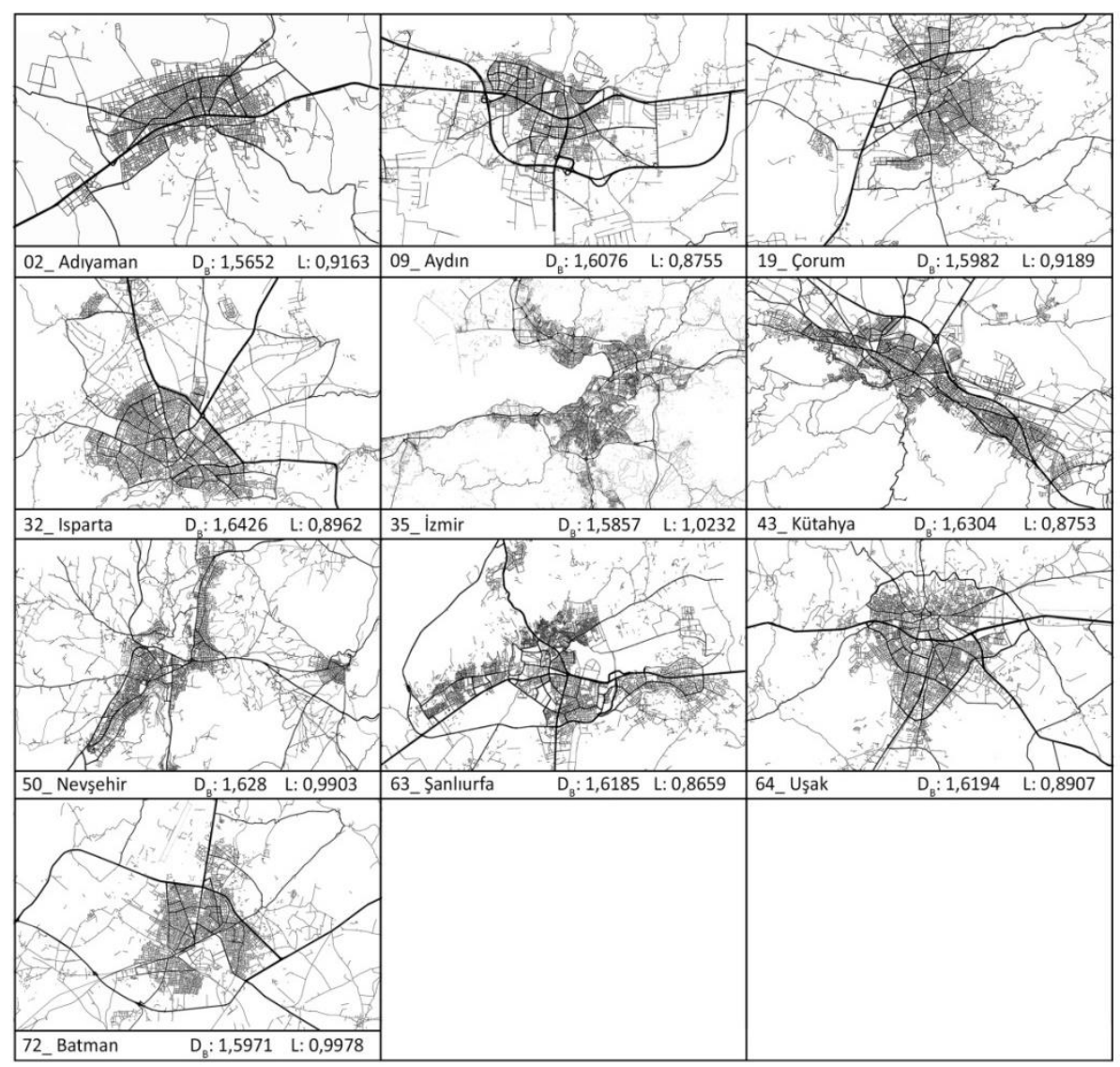

Figure 14. Cities in Cluster 6. 
Cluster 7 is composed of medium and large-size cities with fractal values that are above average, lacunarities are above average and close to maximum value. Although Ankara has a maximum $\mathrm{D}_{\mathrm{B}}$; it is in this cluster due to its high Lac value as a result of its hollow growth towards the surrounding of the city (Figure 15).

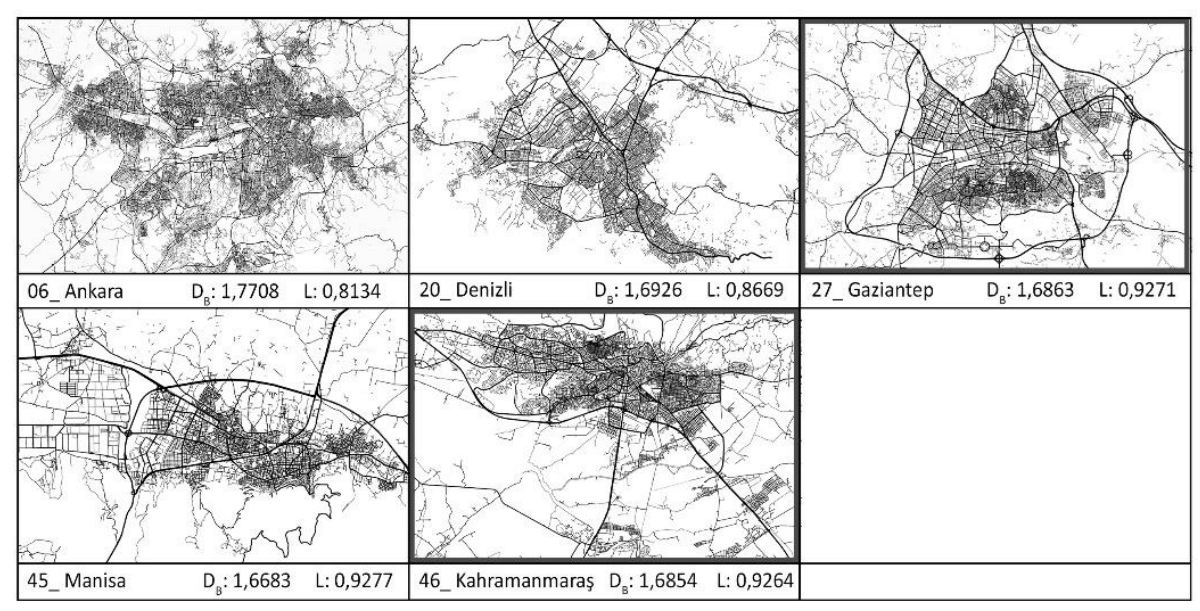

Figure 15. Cities in Cluster 7.

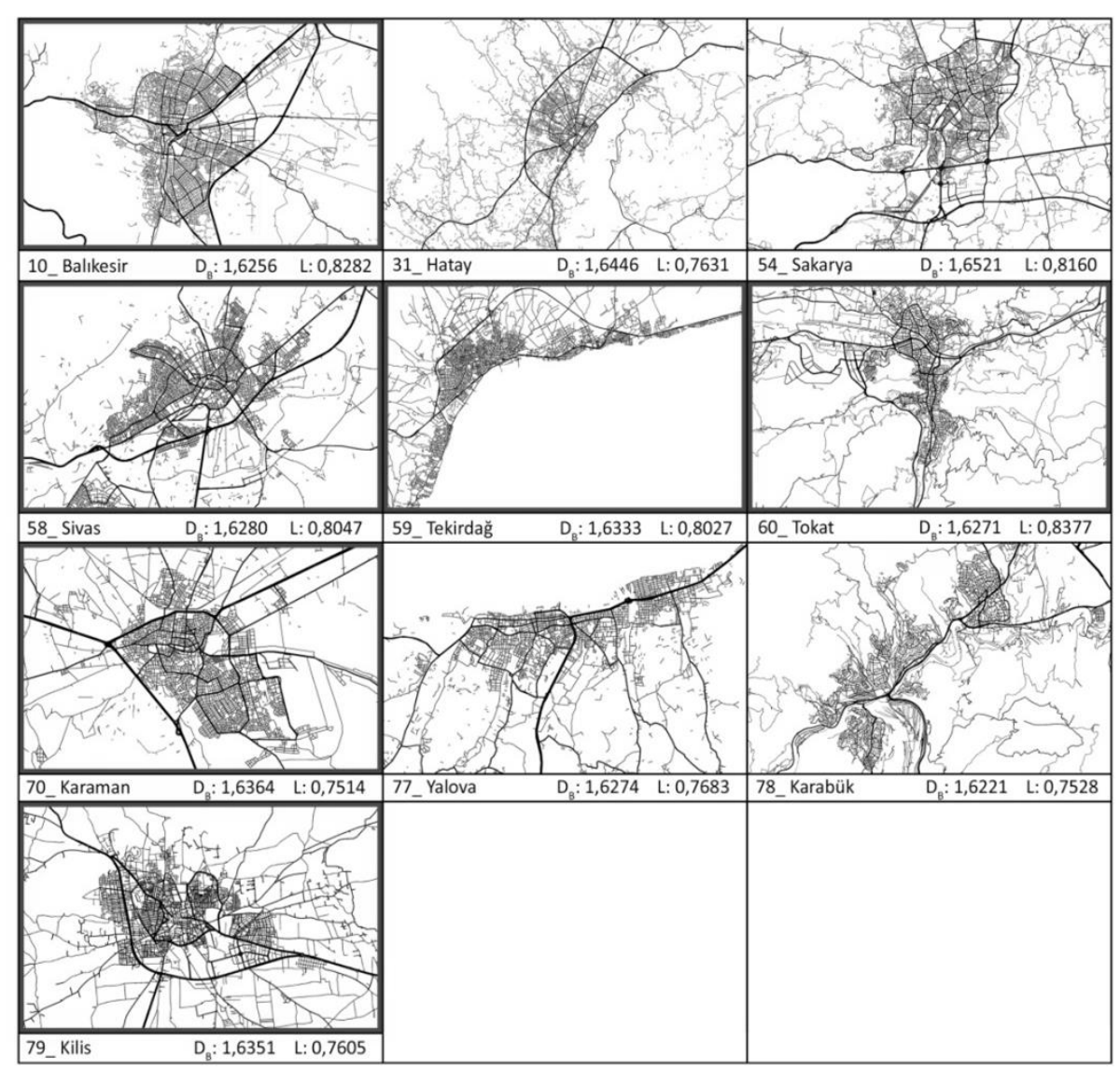

Figure 16. Cities in Cluster 8. 
While the $\mathrm{D}_{\mathrm{B}}$ values of the cities in Cluster 8 are just above average, their lacunarities are average. Here, it is seen that small-size cities such as Kilis, Karabük, Yalova, Karaman, Tokat, Sivas and medium-size cities such as Balıkesir, Hatay, Sakarya and Tekirdağ are located in the same cluster (Figure 16). While the $\mathrm{D}_{\mathrm{B}}$ values of the cities in Cluster 9 are above average, their lacunarities are average level. The reason why a mega city such as İstanbul is included in this cluster is the sprawling of urban pattern along the coast (Figure 17).

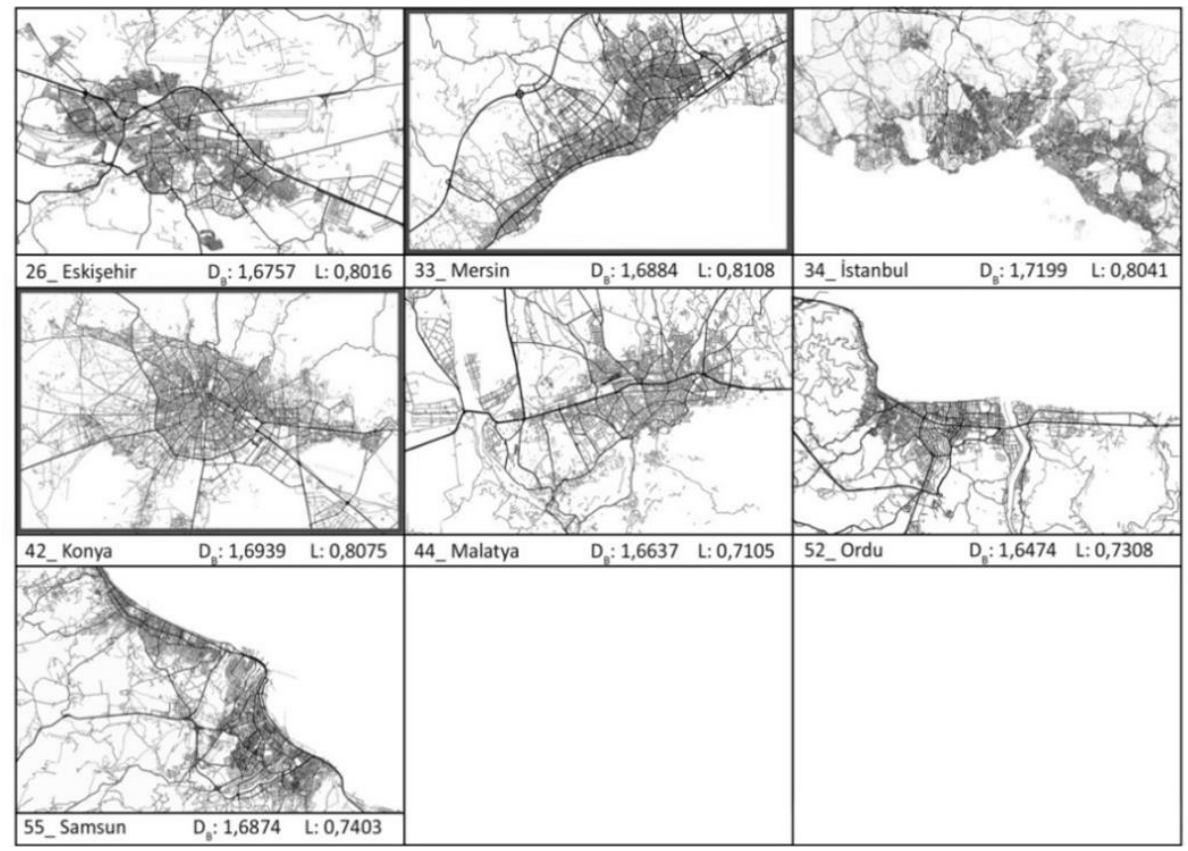

Figure 17. Cities in Cluster 9.

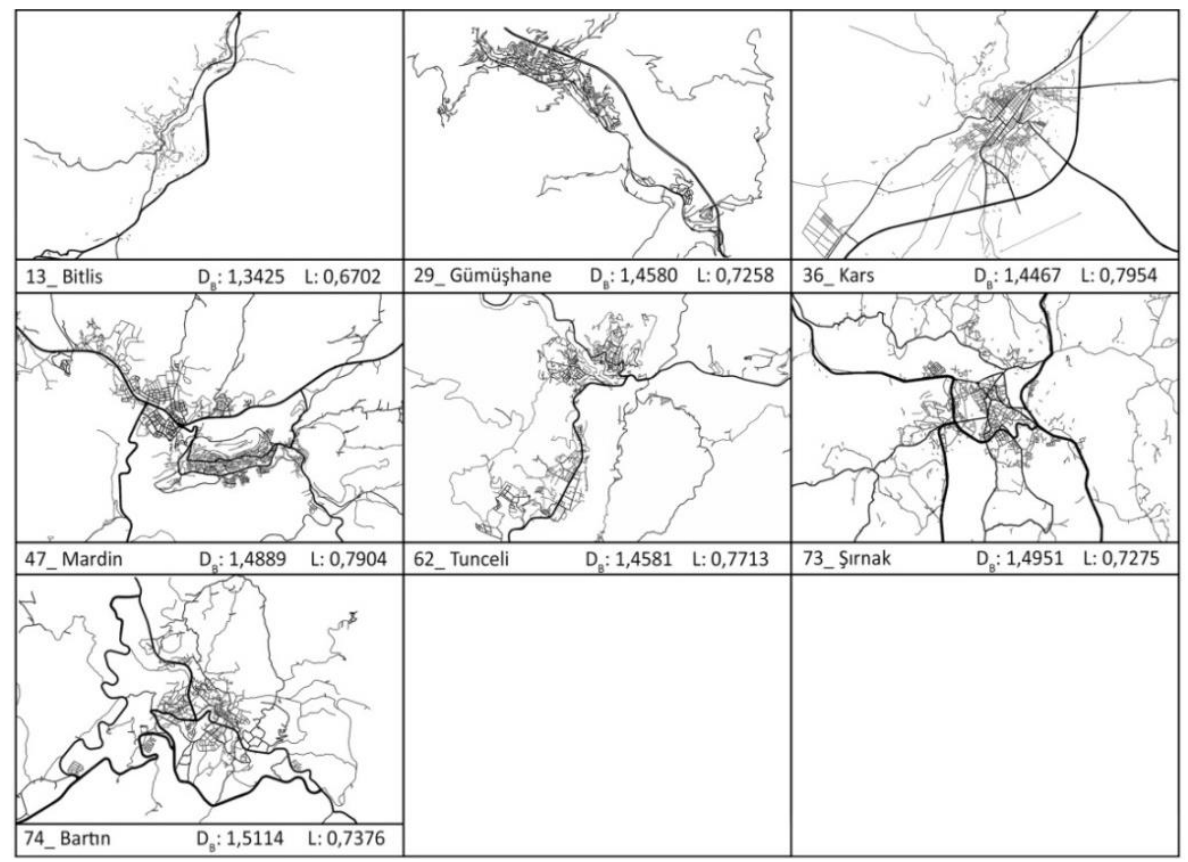

Figure 18. Cities that are outside the clusters and are considered Cluster 10. 
Bitlis, Gümüşhane, Kars, Mardin, Tunceli, Şırnak, Bartın cities that are not included in the dendogram. They were evaluated as a separate cluster in themselves because their fractal dimensions are low at minimum values and lacunarity values are average level. These are usually small-size cities established in the rugged terrain located in the east of Turkey. Urban tissues in this cluster, which is similar to Cluster 5 with low Db values, differs from Cluster 5 due to the lower Lac values (Figure 18).

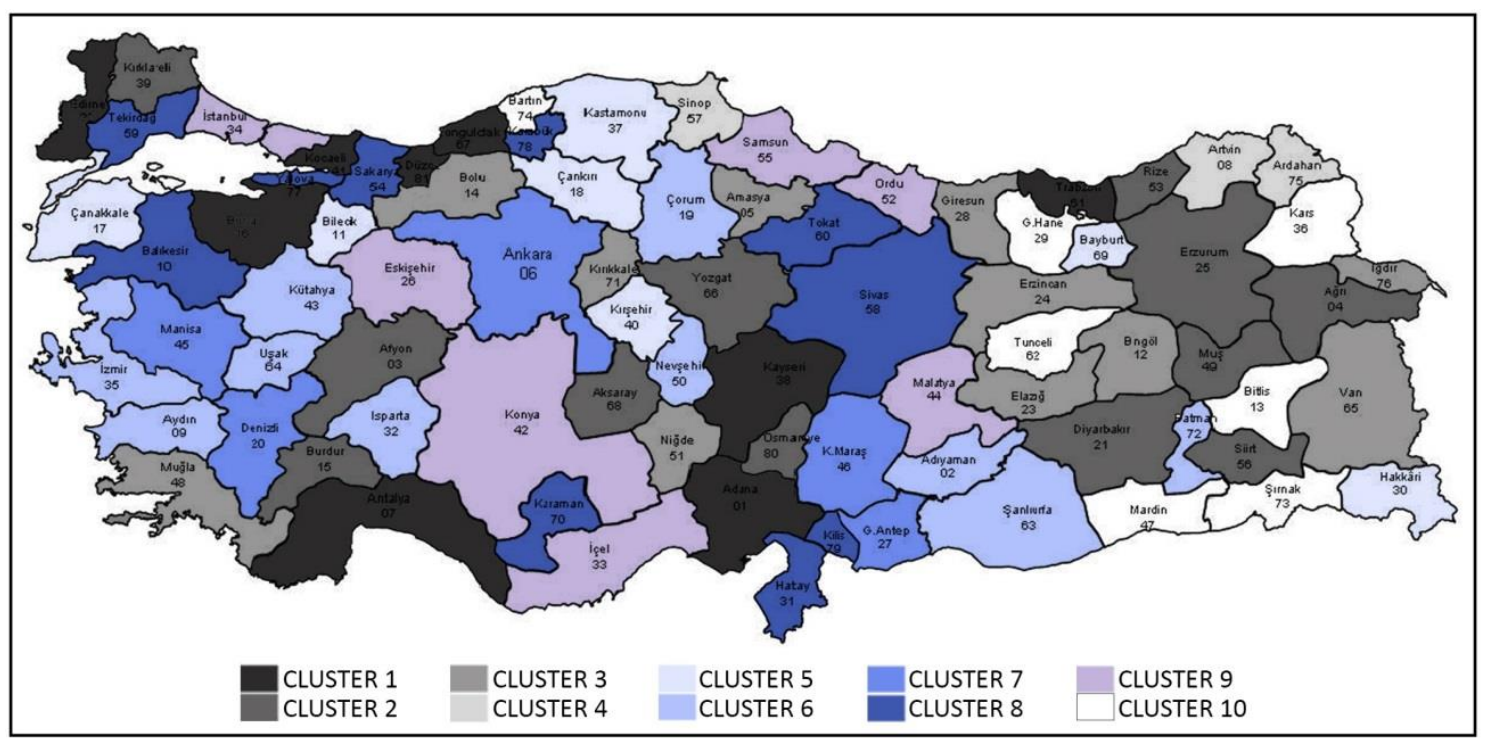

Figure 19. Distribution of cities belonging to each cluster within the country.

While the locations of cities that in the same cluster and showing similar values are sometimes clustered in certain regions; it is seen that the distribution within the country is mostly different. For example, in Cluster 4, Artvin and Ardahan while the mountainous cities located in northeastern Turkey; Sinop is a port city on the northern Black Sea coast. As another example, it is seen that cities such as Rize, Erzurum, Muş, Ağrı, Diyarbakır, Siirt in Cluster 2 are concentrated in the eastern part of the country. In Turkey map in Figure 19, the distribution of cities belonging to each of the clusters is shown in different colors.

\section{DISCUSSION AND CONCLUSION}

In this study, urban pattern morphology of 81 provinces in Turkey was analyzed over road network maps prepared with equal levels of detail using satellite images of March 2020. The aspects that distinguish this study from previous studies are that it focuses only on urban patterns, the level of detail of the analyzed maps is quite high, and provides the opportunity to compare urban patterns of different scales. The similarities and differences between the obtained $\mathrm{F}$ and Lac data were investigated by hierarchical clustering diagram. Finally, whether the provinces are related to the 2018 population data and the 2018 gross domestic product per capita by provinces (dollar) numbers with the correlation analysis were examined. As a result of the research: 
- It is understood that fractal size and lacunarity coefficients provide very useful data for classifying cities. According to these values, 81 Turkish cities are grouped into 10 clusters.

- When looking at the clusters, it can be said that cities with similar scales such as large and medium-large, small and medium size are likely to be located in the same cluster. Especially, cluster 10 formed by small-size cities, cluster 5 formed by small and medium-small-size cities, and cluster 6 of medium-size cities (excluding Izmir) were observed to be physically more similar in itself. Although it has been stated that, "the effect of diverse urban morphologies is evident in smaller cities, in the mean, the larger cities are alike" (Shreevastava et al., 2019) in this study, it was concluded that the small-size urban patterns were more similar.

- Another remarkable point is the two-moded distribution of fractal dimensions. In this distribution, it has been found that the physical and economic development levels of Cluster 1, Cluster 7 and Cluster 9 cities where fractal values are measured above the average are generally better. Socio-economic findings in the article "Development of urban hierarchies at the country and regional levels in Turkey" published by Kaya and Dökmeci (2017) also support this hypothesis.

- The exception of a mega-city like Izmir with its low fractal dimension and high lacunarity coefficient is due to the sprawl of the urban pattern. Similarly, the fact that large-size cities such as Istanbul, Antalya and Mersin are being in different clusters and show high lacunarity is related to the urban sprawl they live linearly along the coast. A study measuring the sprawl of Istanbul between 1975 and 2005 supports these results (Terzi and Kaya, 2011). Lagarias and Prastacos (2017) also stated in their article that the existence of the sea for a coastal city led to linear development and that the fractal value in these settlements decreased.

- When the measured fractal and lacunarity values are correlated with each other, and with population and the GDP per capita by provinces that are obtained from the State Institute of Statistics;

$>$ A weak, negative, significant (5 significance level) correlation between fractal dimension and lacunarity. This result shows us that while the fractal dimension increases, the lacunarity value will not decrease in all cases. Gapped or linear development on the outer periphery of large and medium-sized cities with fractal dimensions above-average increases the Lac value (Cluster $7,8,9)$. On the other hand, the lacunarity values of some small-size cities with low fractal dimensions are below average due to their compact structure (Cluster 4, 10). Such situations explain the low significance level of the negative correlation.

$>$ A weak, positive, significant (1\% significance level) relationship between fractal size and population of provinces; and also there is a moderate, positive significant $(1 \%$ significance level) relation between fractal dimension and gross domestic product per capita by provinces. No significant relationship was found between lacunarity and population. This situation can be explained by the different scope of the data. Such as the fact that the share of the population of provincial centers in the total population of provinces varies in different regions, and also being generated income of non-central districts in many provinces.

As mentioned in the introduction, the urban morphology continues to change under the influence of many parameters. In this article, the numerical data obtained for Turkish cities are seen as a starting point for morphological studies investigating the relationships between different variables. 
In future studies, the relationship between fractal and lacunarity data with different variables, such as, altitude of the city, age of the city, $\mathrm{m}^{2}$ unit price of land, etc., and for larger and smaller urban areas can be investigated.

\section{REFERENCES}

Batty, M. (1994). Fractal Cities A Geometry of Form and Function, New York Academic Press.

Bettencourt, A.M. L., Lobo, J., Strumsky, D., \& West, B. G. (2010). Urban Scaling and Its Deviations: Revealing the Structure of Wealth, Innovation and Crime across Cities. PLOS ONE, 5(11). Retrieved from https://doi.org/10.1371/journal.pone.0013541

Borys, P. (2009). On The Relation Between Lacunarity and Fractal Dimension, Acta Physica Polonica B, 40 (5): 1485-1490. Retrieved from https://www.semanticscholar.org/paper/Onthe-Relation-Between-Lacunarity-and-FractalBorys/257db60cbba998f97843f57506c38e37d248e630?p2df

Bovill, C. (1996) Fractal Geometry in Architecture and Design. Birkhauser Boston.

Chen, Y., \& Wang, J. (2013). Multifractal Characterization of urban form and growth: the case of Beijing. Environment and Planning B: Planning and Design, 40(5), 884-904. Retrieved from https://doi.org/10.1068/b36155

Caglioni, M., \& Giovanni, R. (2006). Contribution to the Fractal Analysis of Cities: A Study of the Metropolitan Area of Milan. Cybergeo. Retrieved from https://doi.org/10.4000/cybergeo.3634

Düşündere, T. A. (2019) 1992-2018 Dönemi için Gece Işılklarylla İl Bazında GSYH Tabmini: 2018'de 81 İlin Büyüme Performansı. Türkiye Ekonomi Politikaları Araştırma Vakfı. Retrieved [15 May 2020] from https://www.tepav.org.tr/upload/files/15532365805.Gece_Isiklariyla_Il_Bazinda_GSYH_Tahmini_1992_2018.pdf

Ediz, Ö., \& Çağdaş, G. (2005). Mimari tasarımda fraktal kurguya dayalı üretken bir yaklaşım. itüdergisi/ a mimarlke, planlama, tasarm, 4(1): 71-83. Retrieved from http://itudergi.itu.edu.tr/index.php/itudergisi_a/article/view/943

Ediz, Ö., \& Ostwald, J. M. (2012). The Süleymaniye Mosque: A Computational Fractal Analysis of Visual Complexity and Layering in Sinan's Masterwork. Architectural Research Quarterly (ARQ), 16(2), 171-182. Retrieved from https://doi.org/10.1017/S1359135512000474

Erdoğan, G. (2015). Kent Makroformlarmm Mekan Kullanma Verimliliklerinin Fraktal Boyut İle İncelenmesi. Dokuz Eylül Üniversitesi, İzmir. 
Forsythe, A., Nadal, M., Sheehy, N., Cela-Conde, J. C., \& Sawey, M. (2011). Predicting beauty: Fractal dimension and visual complexity in art. British Journal of Psychology, 102(1): 4970. Retrieved from https://doi.org/10.1348/000712610X498958

Gözübüyük, G. (2007). Farklı Mimari Dillerde Fraktallere Dayalı Form Üretimi. İTÜ, İstanbul.

İlhan, C., \& Özgür, E. (2019). Kent Dokusu Morfolojik Değişiminin Fraktal Geometri Aracıllğıyla Hesaplanmasi: Bursa Örneği. Mimarlk ve Yaşam, 4(1): 117-140. Retrieved from https://doi.org/10.26835/my.546927

Vaughan, J., \& Ostwald, J. M. (2009) Nature and architecture: revisiting the fractal connection in Amasya and Sea Ranch. $43^{\text {rd }}$ Annual Conference of the Architectural Science Association, ANZAScA 2009, University of Tasmania

Karperien, A. (1999-2003). FracLac for ImageJ.

https://imagej.nih.gov/ij/plugins/fraclac/FLHelp/Introduction.htm

Karperien, A., Jelinek, H. F., \& Milošević, N. (2011). Reviewing Lacunarity Analysis and Classification of Microglia in Neuroscience. Proceedings of the 8th European Conference on Mathematical and Theoretical Biology European Society for Mathematical and Theoretical Biology (ESMTB) 2011 MS\#88. Retrieved from https://doi.org/10.13140/2.1.3576.6082

Kaya, H. S., \& Bölen, F. (2017). Urban DNA: Morphogenetic Analysis of Urban Pattern. ICONARP International Journal of Architecture Planning, 5(1), 10-41. Retrieved from https://doi.org/10.15320/ICONARP.2017.15

Kaya, H. S., \& Dökmeci, V. (2017). Development of urban hierarchies at the country and regional levels in Turkey. A/Z ITU Journal of Faculty of Architecture, 14(2), 131-149.

Lagarias, A., \& Prastacos, P. (2017). Estimation of Fractal Dimensions of Mediterranean Cities Using Data For Different Built-Up Densities. 'Cities and regions in a changing Europe: challenges and prospects', Panteion University, Athens, Greece, 5-7 July 2017.

Lagarias, A., \& Prastacos, P. (2018). Comparing the urban form of South European cities using fractal dimensions. Environment and Planning B: Urban Analytics and City Science. Retrieved from https://doi.org/10.1177/2399808318820911

Larkham, J. P., \& Adams, D. (2019). Persistence, Inertia, Adaptation And Life Cycle: Applying Urban Morphological Ideas To Conceptualize Sustainable City-Centre Change. ICONARP, 7 (Special issue): 73-94. Retrieved from https://doi.org/10.15320/ICONARP.2019.78

Lynch, K. (1960). The Image of the City, New York: M.I.T. Press.

McAdams, M. A. (2007). Fractal Analysis and the Urban Morphology of A City in A Developing Country: A Case Study of Istanbul. Marmara Coğrafya Dergisi, 15: 149-172. Retrieved from http://dspace.marmara.edu.tr/handle/11424/2515 
Meredith, S. (2018). Two-thirds of global population will live in cities by 2050, UN says. Cnbc archive. Retrieved from https://www.cnbc.com/2018/05/17/two-thirds-of-global-population-willlive-in-cities-by-2050-un-says.html

Ostwald, J. M., \& Vaughan, J. (2016) The Fractal Dimension of Architecture (eBook). Springer International Publishing, Switzerland.

Prastacos, P., Lagarias A., \& Chrysoulakis N. (2017). Using the Urban Atlas dataset for estimating spatial metrics; methodology and application in urban areas in Greece. CyberGeo. Retrieved from https://doi.org/10.4000/cybergeo.28051

Rauch, E. (2019). Introduction to Lacunarity. Eric Rauch online archive. Retrieved [20 December, 2019] from http://groups.csail.mit.edu/mac/users/rauch/lacunarity/lacunarity.html

Reiss, A. M., Lemmerer B., Hanslmeier A., \& Ahammer H. (2016). Tug-of-war lacunarity-A novel approach for estimating lacunarity. Chaos: An Interdisciplinary Journal of Nonlinear Science. Retrieved from https://doi.org/10.1063/1.4966539

Salat, S. (2012). The Fractal Pattern of Cities. Óbuda University e-Bulletin, 3(1): 263-273.

Shen, G. (2002). Fractal dimension and fractal growth of urbanized areas. International Journal of Geographical Information Science, 16(5): 419-437. Retrieved from https://doi.org/10.1080/13658810210137013

Shreevastava, A., Suresh P., Rao C., \& McGrath, G. S. (2019). Emergent Self-Similarity and Scaling Properties of Fractal Intra-Urban Heat Islets for Diverse Global Cities. Physical Review E. Retrieved from https://doi.org/10.1103/PhysRevE.100.032142

Terzi, F., \& Kaya, H. S. (2011). Dynamic spatial analysis of urban sprawl through fractal geometry: The case of Istanbul. Environment and Planning B Planning and Design, 38(1),175-190. Retrieved from https://doi.org/10.1068/b35096

Triantakonstantis, P. D. (2012). Urban Growth Prediction Modelling Using Fractals and Theory of Chaos. Open Journal of Civil Engineering, 2(2): 81-86. Retrieved from https://doi.org/10.4236/ojce.2012.22013

TUIK. (2018). Yullara göre il nüfuslar, 2000-2018. Retrieved from [15 December 2019] http://www.tuik.gov.tr/Start.do

Url-1 Retrieved from [10 December 2019] http://metrocosm.com/history-of-cities/

Url-2 Retrieved from [25 April 2020] https://pudding.cool/2018/10/city_3d/

Url-3 Retrieved from [1 April 2020] Google Maps https://www.google.com/maps/d/edit?mid=1ChqsKJA_yzrrZ52SKp_WXjA0GqJR3Xsv\&ll=4 $0.132092310883536 \% 2 \mathrm{C} 26.421455753221707 \& z=13$ 


\section{CONFLICT OF INTEREST STATEMENT}

No financial support was received for conducting the research and preparation of the article.

\section{AUTHOR CONTRIBUTION STATEMENTS}

Necmi Gürsakal developed the initial idea and concept of the study, did a detailed literature review, did statistical analysis and supervised the project. Ceyda Illhan collected and processed the map data and analysed data. Both authors contributed to the study and methodology design, the interpretation of the data, the writing of the text, the critical review of the study and the final version of the manuscript.

\section{BIOGRAPHIES OF THE AUTHORS}

\section{Ceyda İlhan}

She is an architect and a part-time lecturer at Bursa Uludağ University Department of Architecture. She graduated her bachelor's degree at Uludag University in 2015. Then she completed her master's thesis is titled 'Architectural Pattern Readings by Digital Analysis Methods: Bursa Hisar Region" at same university in 2019. She continues her research on computational design, morphological and typological analysis of the built environment, human and space interactions, space syntax and fractal geometry.

\section{Necmi Gürsakal}

He is Professor of statistics and currently the deputy dean of the Engineering and Architecture Faculty at Fenerbahçe University. Firstly, he studied Chemistry at METU for three years. Then he finished BİTIA and started to work as an assistant in 1976 at the same institution. He worked at Uludağ University Department of Econometrics between 1983-2017. For many years he wrote columns and made television programs in the local newspapers of Hakimiyet and Olay. He worked as consultant in GESİAD, BUSIAD and BTSO. He has many publications in national and international journals and dozens of printed books on statistics, network science, big data, data science and machine learning. 